Oxford Review of Economic Policy, Volume 33, Number 4, 2017, pp. 541-571

\title{
An invitation to market design
}

\section{Scott Duke Kominers, * Alexander Teytelboym,** and Vincent P. Crawford***}

\begin{abstract}
Market design seeks to translate economic theory and analysis into practical solutions to real-world problems. By redesigning both the rules that guide market transactions and the infrastructure that enables those transactions to take place, market designers can address a broad range of market failures. In this paper, we illustrate the process and power of market design through three examples: the design of medical residency matching programmes; a scrip system to allocate food donations to food banks; and the recent 'Incentive Auction' that reallocated wireless spectrum from television broadcasters to telecoms. Our lead examples show how effective market design can encourage participation, reduce gaming, and aggregate information, in order to improve liquidity, efficiency, and equity in markets. We also discuss a number of fruitful applications of market design in other areas of economic and public policy.
\end{abstract}

Keywords: matching, auctions, trading, scrip, liquidity, efficiency, equity, allocation rules, marketplaces, market design

JEL classification: D47, C78, D44, D82, D02, D51, D71, D61, D62, D63

* Entrepreneurial Management Unit, Harvard Business School; Department of Economics, Center of Mathematical Sciences and Applications (CMSA), and Center for Research on Computation and Society, Harvard University; and National Bureau of Economic Research, e-mail: kominers@fas.harvard.edu

** Department of Economics and St Catherine's College, University of Oxford; and Institute for New Economic Thinking (INET), Oxford Martin School, e-mail: alexander.teytelboym@economics.ox.ac.uk

*** Department of Economics and All Souls College, University of Oxford; and Department of Economics, University of California, San Diego, e-mail: vincent.crawford@economics.ox.ac.uk

This project was launched while Kominers was a Visiting Fellow at the Oxford Martin School. He is grateful to the Oxford Martin School for its funding and hospitality, and also appreciates the support of the National Science Foundation (grants CCF-1216095, SciSIP-1535813, and SES-1459912), the Harvard Milton Fund, the Ng Fund of the CMSA, and the Human Capital and Economic Opportunity Working Group (HCEO) sponsored by INET. This paper was written while Teytelboym was the Otto Poon Research Fellow at INET. The research leading to these results received primary funding from the European Research Council (ERC) under the European Union's Seventh Framework Programme (FP7/2007-2013)/ERC grant agreement no. 339179. The contents reflect only the authors' views and not the views of the ERC or the European Commission, and the European Union is not liable for any use that may be made of the information contained therein. The University of Oxford, All Souls College, and the University of California, San Diego also provided research support.

We are deeply grateful to Thomas R. Eisenmann for foundational ideas that inspired part of this work, and thank Eric Budish, Jiafeng Chen, Âriel de Fauconberg, David Delacrétaz, Steven Durlauf, John William Hatfield, Dieter Helm, Cameron Hepburn, Ravi Jagadeesan, Paul Klemperer, Paul Kominers, Jonathan

doi:10.1093/oxrep/grx063

(C) The Authors 2017. Published by Oxford University Press.

This is an Open Access article distributed under the terms of the Creative Commons Attribution License (http://creativecommons.org/licenses/by/4.0/), which permits unrestricted reuse, distribution, and

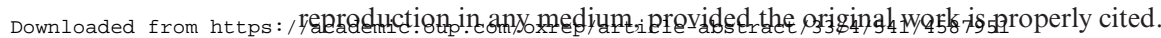




\section{Introduction}

Market design seeks to turn economic theory and analysis into practical solutions to real-world problems. Market designers iterate back and forth between theory and practice in order to improve the function of markets - settings in which economic incentives matter. The goal of the market design approach is to mitigate some of the frictions and externalities that prevent markets from reaching the first best, ${ }^{1}$ while at the same time aligning market outcomes with society's objectives beyond pure economic efficiency.

In practice, market design is largely concerned with the rules that guide market transactions and the infrastructure that enables those transactions to take place-two ingredients that jointly constitute marketplaces (Eisenmann et al., 2006; Eisenmann and Kominers, 2017). Rules may take many forms, ranging from simple guidelines (e.g. 'swipe right' to accept a date on Tinder) ${ }^{2}$ to dozens of pages of minutiae (as are common, for example, in government procurement and spectrum auctions). Infrastructure may be physical (e.g. a room in which market participants can meet and negotiate), but need not be - infrastructure might, for example, be technological, legal, or social.

Marketplaces need not be centralized, but they must coordinate and facilitate transactions. For example, over-the-counter financial marketplaces enable transactions without centralizing them, whereas limit order books centralize all transactions for particular financial instruments. Likewise, a company may be sold through a multilateral negotiation or a single auction (Bulow and Klemperer, 1996, 2009). Marketplaces can be run freely by firms, regulated, or organized by governments; they may or may not involve monetary transfers; and they may or may not require/enforce participation. In other words: marketplaces, like markets, can take almost any form.

In recent years, market(place) design has evolved into a field in its own right, involving not just economists, but also computer scientists, operations researchers, engineers, and practitioners (Klemperer, 2004; Milgrom, 2004; A. E. Roth, 2015; Fisman and Sullivan, 2016).

This issue of the Oxford Review of Economic Policy presents a number of policy and business domains in which market design has played — and continues to play — a crucial role. Richard Schmalensee and Robert Stavins (2017) consider the success of permit trading in reducing emissions of lead, sulphur dioxide, nitrogen oxides, and carbon dioxide. Peter Cramton (2017) examines the organization of electricity markets,

Landman, Kevin Leyton-Brown, Daniel Marszalec, Colin Mayer, Ken Mayhew, Paul Milgrom, David Parkes, Canice Prendergast, Alvin Roth, Benjamin Roth, Ilya Segal, and Charlie Ughetta for insightful conversations and suggestions. We also thank the authors of articles in this issue and participants at the Oxford Review of Economic Policy editorial seminar on market design - including Abi Adams, Mohammad Akbarpour, Elizabeth Baldwin, Dhruva Bhat, Michael Brolley, Simon Cowan, Sam Fankhauser, Thayer Morrill, and Nir Vulkan - for their thoughtful commentary. We are indebted to Alison Gomm for her fine-brush copyediting and flawless organization of the editorial seminar.

${ }^{1}$ In theory, equilibrium in perfectly competitive, frictionless markets obtains the first best—i.e. Paretoefficient outcomes (Smith, 1778; Edgeworth, 1881; Hayek, 1945; Arrow and Debreu, 1954; McKenzie, 1954; Coase, 1960). In practice, institutions such as property rights (Coase, 1960; Acemoğlu et al., 2001), money supply (Friedman and Schwartz, 1963), efficient courts (Djankov et al., 2003), insurance (Arrow, 1964), public information channels (Hayek, 1945; Fama et al., 1969), and consumer protection (Akerlof, 1970) are essential for supporting markets and making them reliable for participants.

${ }^{2}$ In Tinder, a mobile dating app, swiping right across a phone screen allows users to accept other users as possible dating partners; swiping left indicates rejection. 
with a particular focus on the Electric Reliability Council of Texas (ERCOT), which manages a large-scale, liberalized electricity market. Estelle Cantillon (2017) discusses how matching theory has improved the efficiency and fairness of primary and secondary school admissions throughout Europe and the United States. Benjamin Edelman (2017) analyses a number of strategies that online marketplaces adopt in order to retain and engage their customers. Albert S. Kyle and Jeongmin Lee (2017) propose a strategy for reducing the rents accruing to high-frequency traders who seek to arbitrage across financial marketplaces. Tayfun Sönmez and Utku Ünver (2017) describe recent progress in the design of lifesaving paired kidney exchanges, and discuss the possibilities of liver, lung, and multi-organ exchange. Finally, Shengwu Li (2017) offers a new perspective on the ethical foundations of market design. ${ }^{3}$ He proposes that the market designer's job is to optimize the market outcome with respect to society's preferred objective function, while 'maintain[ing] an informed neutrality between reasonable ethical positions' regarding the objective function itself (as well as the associated constraints). ${ }^{4}$

In this paper, we illustrate the process and power of market design through three examples: the design of medical residency matching programmes; a scrip system to allocate food donations to food banks; and the recent 'Incentive Auction' that reallocated wireless spectrum from television broadcasters to telecoms. In each case, we explain the underlying problem and design objectives, describe the solution in terms of rules and infrastructure, and draw lessons for other markets. Our examples illustrate how effective market design can encourage participation, reduce gaming, and aggregate information, in order to improve liquidity, efficiency, and equity in markets.

The examples we consider also reveal that market design is an adaptive process with complex objectives and constraints. Market designers often work in contexts in which inequality and fairness are first-order concerns, and in which market participation cannot be enforced (and so must be treated as endogenous). Some settings also involve social and legal restrictions on transactions (e.g. a complete prohibition on monetary payments) and/or fiendish computational problems.

To tackle poor market performance in the real world, market designers draw upon a number of fields of economic theory including mechanism design, auction theory, matching theory, social choice, and industrial organization, as well as work in experimental economics, computer science, and operations research. The market designer's toolkit offers promise for tackling problems in a range of new domains. Alongside digital platforms, organ exchanges, and financial markets - all of which are explored in further detail in this issue - we discuss a number of prospective future applications, including refugee resettlement, biodiversity conservation, transportation, and intellectual property. Some of the applications we describe would require entirely new marketplaces; others would necessitate only minor adjustments to existing rules and transaction infrastructure. Without a doubt, the settings we discuss offer many exciting theoretical and practical directions for market design.

3 Understanding ethics in market design requires us to go beyond the ethics of market redistribution of society's resources (Rawls, 1971; Nozick, 1974; Sen, 1985), the limits of commercial exchange (Smith, 1759; Sandel, 2012), and the economic borders of the state (Keynes, 1936; Hicks, 1939; Hayek, 1945; Helm, 1990) none of which we tackle directly here.

${ }^{4}$ Of course, as Li (2017) notes, market design experts should — and do_-play a crucial role in the public discourse about what the objective function and constraints ought to be. 


\section{Three illustrations of market design in practice}

\section{(i) Medical residency matching}

\section{The problem}

After completing medical school, doctors in the United States and United Kingdom (as well as many other countries) take up training residencies in their fields of specialization. In 2017, there were over 31,000 residency positions in the United States alone.

From the early 1900s to 1945, the American medical residency labour market faced a crisis of unravelling. Offers would be made earlier and earlier each year and, eventually, doctors found themselves accepting residency positions before they had completed much of their training or had opportunities to explore specialization fields. Unravelling led to significant mismatch-doctors often turned out to be ill-suited for the residencies they had accepted. But unravelling was a product of the incentives created by the residency matching market - while all the hospitals agreed that offers should be made later, each individual hospital wanted to make offers earlier than all the others, so as to lock in high-quality candidates (A. E. Roth and Xing, 1994, 1997; A. E. Roth, 2008a,b).

In 1945, the Association of American Medical Colleges (AAMC) imposed a new set of rules aimed at making sure that all residency offers were made on the same day; this at least partially succeeded in coordinating timing, but made market-clearing chaotic and congested. Hospitals and candidates would contract and re-contract by making and accepting offers in a frenzy of phone calls - and many positions were left unfilled at the end of the day. In the 1950s, the AAMC centralized the residency matching system further, organizing a clearinghouse that solicited preference lists from doctors and hospitals and then assigned residencies based on a version of what is now called the deferred acceptance algorithm (Gale and Shapley, 1962; A. E. Roth, 1984; A. E. Roth and Sotomayor, 1990). In the deferred acceptance algorithm, one side sequentially 'proposes' to the other side of the market. At each stage, the proposal recipients 'hold' their favourite proposals and reject all others. Rejected agents then propose to their next most preferred partners, and the algorithm continues, eventually terminating when no agent has new proposals to make. ${ }^{5}$

The original medical residency match, now called the National Resident Matching Program (NRMP), used a hospital-proposing version of the deferred acceptance algorithm and ran successfully for several decades. However, by 1995 the NRMP faced a new difficulty: medical students were marrying each other in growing numbers (driven in large part by an influx of women into medical professions), yet the NRMP provided no mechanism for couples to express preferences for co-located residencies (A. E. Roth and Peranson, 1999; A. E. Roth, 2002). Couples were thus often forced to negotiate jobs outside the match; this threatened to lead back to the chaos of the late 1940 s. 


\section{The solution}

The original NRMP appears to have been successful in part because the deferred acceptance algorithm produces an outcome that is stable in the sense that no doctor and hospital mutually prefer each other to their assigned matches. ${ }^{6}$ Stable mechanisms have been shown to reduce unravelling, and have been key drivers of successful residency matching programmes throughout the US and UK (A. E. Roth, 1990, 1991; Kagel and A. E. Roth, 2000; Niederle and A. E. Roth, 2003; B. N. Roth and Shorrer, 2017).

In the presence of couples, however, the existence of stable matchings cannot always be guaranteed (A. E. Roth, 1984; Klaus and Klijn, 2005; Biró and Klijn, 2013; Hatfield and Kominers, 2017). Consequently, A. E. Roth and Peranson (1999) developed a subtle extension of deferred acceptance that enabled couples to submit preferences jointly, while carefully mitigating as many market instabilities as possible. A. E. Roth and Peranson (1999) then demonstrated via simulation that their mechanism was likely to find stable matchings in the NRMP context in practice.

An additional adjustment, originally suggested by A. E. Roth (1984), was to switch to a doctor-proposing version of deferred acceptance, as that algorithm has substantial benefits for doctors. Indeed, doctor-proposing deferred acceptance finds the best stable outcome from the doctors' perspective, and is strategyproof in the sense that it removes any incentive for doctors to misrepresent their preferences over hospitals (A. E. Roth, $2002,2008 a, b) .{ }^{7}$ Ensuring strategic simplicity for doctors was of particular importance because doctors (unlike hospitals) are short-run players - they only go through the NRMP once, and thus do not have opportunities to learn the workings of the system over time. ${ }^{8,9}$

The NRMP adopted the (doctor-proposing) A. E. Roth and Peranson (1999) mechanism in 1997, and has used it successfully since then. Every year so far, the NRMP has found stable doctor-hospital matches even in the presence of couples, and recent theoretical work has helped us start to understand why. ${ }^{10}$

Rules: Doctor-proposing deferred acceptance algorithm, with the A. E. Roth and Peranson (1999) modification to allow for couples.

Infrastructure: Annual centralized system that coordinates preference submission for doctors and hospitals and implements the matching algorithm.

\footnotetext{
${ }^{6}$ It is possible, of course, that a given doctor $d$ might not receive his or her top-choice hospital—but in this case, all the hospitals that $d$ prefers to his or her assigned match have doctors they prefer to $d$. Likewise, no hospital can find a doctor that it prefers to its assigned doctors and who would be willing to switch. Thus, stability eliminates incentives for doctors and hospitals to try to negotiate new jobs after the match.

${ }^{7}$ Strictly speaking, these properties hold in the absence of couples.

${ }^{8}$ It is worth noting, however, that some recent evidence has indicated attempts at manipulation of the NRMP (Rees-Jones, forthcoming) and even of stable, strategyproof mechanisms (Hassidim, Romm, and Shorrer, 2016; Hassidim, Marciano, Romm, and Shorrer, 2017b).

9 Unfortunately, there is no stable matching mechanism that eliminates preference misrepresentation incentives for both sides of the market at once (Dubins and Freedman, 1981; A. E. Roth, 1982; Sönmez, 1997; P. Chen et al., 2016).

${ }^{10}$ Indeed, recent work has shown that in sufficiently large matching markets, stable outcomes are likely to exist even in the presence of couples (Kojima and Pathak, 2009; Azevedo et al., 2013; Kojima et al., 2013; Ashlagi et al., 2014; Azevedo and Hatfield, 2015; Che et al., 2015; Jagadeesan, 2017).
} 


\section{Related applications}

Centralized matching mechanisms are used successfully in a number of contexts beyond medical residency matching. School choice systems throughout the United States and European Union use variants of the deferred acceptance mechanism to match students to schools; in school choice contexts, requiring stability corresponds to eliminating justified envy among participants. ${ }^{11}$ Similar systems are used to assign lawyers (Dimakopoulos and Heller, 2015) and teachers (Hatfield and Kominers, 2015) to traineeships in Germany, to match psychology students to Masters programmes in Israel (Hassidim, Romm, and Shorrer, 2017a), and to assign cadets to branches of military service (Sönmez and Switzer, 2013; Sönmez, 2013).

To adapt the deferred acceptance algorithm for broader applications, economists have explored ways of incorporating affirmative action and other priority constraints ${ }^{12}$ and specifying contract terms beyond who matches with whom. ${ }^{13}$ More recent work has shown that generalizations of the deferred acceptance algorithm can also be used to clear networked markets (Ostrovsky, 2008; Westkamp, 2010; Hatfield and Kominers, 2012; Hatfield et al., 2013; Fleiner et al., 2017; Morstyn et al., 2017).

Not all labour markets can be centralized easily, however. One particularly stark case is the market for federal law clerks in the United States, in which unravelling has been a persistent problem for many years, despite multiple attempts to reorganize the marketplace (Avery et al., 2001, 2007). The key problem in the law clerk market appears to be one of market power: because federal judges have many opportunities to affect clerks' future careers, they exert so much authority that clerks are unable to turn down (or renege upon) early job offers. ${ }^{14,15}$ It is still unclear exactly when, in general, stable matching can encourage full participation, as it appears to in the NRMP ${ }^{16}$ although recent work of B. N. Roth and Shorrer (2017) gets close to an answer to this question.

\section{(ii) Allocating food donations to food banks}

\section{The problem}

Feeding America, a large non-profit organization, provides nutritional support for $46 \mathrm{~m}$ Americans through a network of food banks.

11 Elimination of justified envy requires that no student should be denied a place at a preferred school if a student with a lower priority has been admitted to that school (Abdulkadiroğlu and Sönmez, 2003; Abdulkadiroğlu, Pathak, and A. E. Roth, 2005a; Abdulkadiroğlu, Pathak, A. E. Roth, and Sönmez, 2005b; Pathak, 2011; Cantillon, 2017).

12 Priority constraints might include quotas or reserves for certain types of students (Abdulkadiroğlu, 2005; Kojima, 2012; Hafalir et al., 2013; Ehlers et al., 2014; Aygün and Bó, 2016; Doğan, 2016; Kominers and Sönmez, 2016; Aygün and Turhan, 2017; Dur et al., forthcoming) or distributional preferences over all student types (Kamada and Kojima, 2012, 2015; Echenique and Yenmez, 2015).

13 Contract terms could include, for example, salaries and position assignments (Crawford and Knoer, 1981; Kelso and Crawford, 1982; Fleiner, 2003; Hatfield and Milgrom, 2005; Hatfield and Kominers, 2017).

14 This is compounded by the fact that judges have found it difficult to reach a collective agreement to centralize their matching process.

15 By contrast, the economics academic job market has achieved a surprising degree of centralization compared to other disciplines (Coles et al., 2010; Bandyopadhyay et al., 2013).

16 Niederle and A. E. Roth $(2003,2005)$ report a fascinating case study in which a shock to the supply of positions in the stable matching system for gastroenterology fellowships caused the matching process to collapse for more than a decade. 
Prior to 2005, Feeding America allocated centrally received donations using a rough proxy based on the demographics and populations of its food banks' catchment areas. Feeding America would offer each donation it received to food banks according to a ranking of perceived need. Any time a food bank accepted a donation, it would be responsible for pick-up and storage; any time it refused, Feeding America would offer the donation elsewhere. Food banks that were offered donations would not be contacted again for a while, irrespective of whether they accepted or rejected their offers. That is, Feeding America was rationing offers of donations, rather than donations themselveseffectively, refusals were treated like indications of lower need.

Rationing offers was widely perceived as fair-but it was also quite inefficient. Food banks receive supplemental donations from outside Feeding America's system - so in principle a food bank might have to refuse offers due to unobservable, transitory supply shocks. (If an outside yoghurt donation fills up a food bank's refrigerators, then that food bank does not have the capacity to accept a dairy donation immediately, even if it would be glad to accept such a donation a week later.) Importantly, some food banks also had to turn down large donations simply because they could not afford to pay the associated transport costs. And many food banks would accept offers they did not especially want, fearing that refusal would be interpreted as an indication of low need, and lead to fewer offers in the future.

\section{The solution}

In 2005, in consultation with a team of academics from the University of Chicago, Feeding America switched from rationing offers to a marketplace solution. Each day, Feeding America now operates spot markets for food donations (cleared via first-price, sealed-bid auctions), using a scrip currency called 'shares' (Prendergast, 2017). ${ }^{17}$ The presence of 'clearing prices' — even if denominated in scrip _ ensures an efficient allocation of food donations. Moreover, the differences in clearing prices reveal the aggregate marginal rates of substitution for different food items (boxed pasta and frozen chicken, for example, turn out to be far more valuable than soda). Shares themselves are distributed according to perceived need-and because the currency is internal to the Feeding America system, better-resourced food banks are not privileged over others, as they would be if cash were used instead of scrip.

Feeding America's marketplace features a number of design advantages beyond just the move to market-based allocation. Food banks can post their extra outside donations into the marketplace and 'sell' them for scrip. Additionally, smaller food banks can access scrip-denominated credit, and can bid together and split transportation costs. Because donations are posted centrally and prices respond to demand, virtually any donation can be placed with some food bank; this has reduced food waste dramatically and enabled Feeding America to take in hundreds of millions of pounds of new donations. Prendergast (2017) has estimated that the increase in accepted donations over the first year of the marketplace enabled Feeding America's food bank network to feed roughly 55,000 additional people per day. Moreover, in order to maintain its commitment to fairness, every day Feeding America redistributes the scrip paid by food

17 The reason for using first-price auctions rather than, say, second-price auctions (which are nonmanipulable) was that food bank managers found first-price auctions simpler. 
banks that 'bought' donations, so that smaller food banks benefit from each auctioneven those they lose to larger food banks.

Using scrip enables Feeding America to gather dispersed and private information about food banks' preferences into a price signal, just as a competitive market would (Hayek, 1945). Yet at the same time, food allocation is not just 'left to the free market'-Feeding America ensures fairness through its daily redistribution of scrip. Thus, Feeding America's food donation marketplace illustrates the power of market mechanisms as designs that can operate successfully outside the traditional market economy.

Rules: First-price, multi-item, sealed-bid auctions (that allow for joint bids), followed by a scrip reallocation procedure.

Infrastructure: Daily, scrip-based, electronic auction platform for posting food donations and submitting bids, along with a scrip account for each food bank.

\section{Related applications}

One of the reasons why the Feeding America marketplace has run so well is that shares are redistributed daily, and thus have essentially maintained their value. By contrast, when the exchange value of scrip varies substantially over time (or across market participants), scrip money supplies can suffer from bubbles and crashes (Kash et al., 2012, 2015). The (in)famous Capitol Hill babysitting co-op, in which couples exchanged scrip corresponding to baby-sitting time, provides a vivid illustration. After a negative shock to the supply of scrip (which arose for administrative reasons), many couples stopped going out and started hoarding scrip; the value of scrip then rose sharply, and all babysitting in the co-op stopped (J. Sweeney and R. J. Sweeney, 1977).

Scrip currency is used fairly commonly in marketplaces, despite the inherent macropolicy risks. One recent application of scrip has been in course allocation at business schools (where most courses are optional, and many of the popular courses are oversubscribed; see Sönmez and Ünver (2010), Budish (2011), and Budish and Cantillon (2012)). In the business school context, using scrip currency imposes a budget constraint on students, forcing them to internalize trade-offs among their most preferred courses. Thus scrip allows students to express the relative intensities of their preferences over courses; in principle, this should allow registrars to allocate courses to the students who value them most highly, just as a competitive market would. ${ }^{18}$ But scrip value fluctuation is a substantial problem in many business school course allocation settings. Business schools often use mechanisms that behave as if scrip savings have value on their own, even though the scrip is worthless outside the course allocation system; this results in students missing out on courses they want while being left with large supplies of scrip (Sönmez and Ünver, 2010), ${ }^{19}$ as well as in graduating students attempting to spend all their remaining scrip at once, artificially inflating course prices (Budish, 2011). Recently, Budish (2011) showed

18 Having some cardinal preference information allows the designer to Pareto-improve on outcomes achieved with only ordinal rankings of courses; for that same reason, Crawford (2008) suggested introducing flexible salaries into the NRMP, which currently collects only ordinal preferences over programmes and residents.

19 A similar problem arose in the first phase of the EU Emissions Trading Scheme. The EU decided that member states could choose whether to allow first-phase (2005-7) permits to be used in the second phase (2008-12). But when the verified emission numbers for 2005 were revealed in April 2006, it became clear that there was a large oversupply of permits and the price of first-phase carbon permits collapsed to nearly 0 (Alberola et al., 2008). 
how to get around both aggregate- and individual-level scrip value fluctuation by using a pseudo-market mechanism with induced budgets and (approximately) full marketclearing in every semester (see also Hylland and Zeckhauser (1979); Bogomolnaia and Moulin (2001); Budish et al. (2013); Liu and Pycia (2016)). The Budish (2011) 'Course Match' mechanism has recently been adopted and used successfully at the University of Pennsylvania's Wharton School (Budish and Kessler, 2016; Budish et al., 2016).

\section{(iii) The US wireless spectrum Incentive Auction}

\section{The problem}

Wireless spectrum is a valuable but limited resource. Allocating spectrum licences is now a classic market design problem - economists have been designing and implementing successful spectrum auctions since the early 1990s (Milgrom, 1989, 2000, 2004; McAfee and McMillan, 1996; Binmore and Klemperer, 2002; Klemperer, 2002, 2004; Cramton et al., 2011). ${ }^{20}$

In the United States, some of the most useful spectrum - able to penetrate concrete in cities and travel long distances to cover rural areas - was allocated early on to television broadcasters. But today, fewer people watch broadcast television, and there is substantial demand for mobile broadband spectrum to support wireless applications. Thus, it makes sense to repurpose some of the broadcast spectrum for telecom use.

Since telecoms often place higher values on spectrum than television broadcasters do, one might expect to observe widespread sale of spectrum licences from broadcasters to telecom companies. However, spectrum exchange is complicated: broadcasters hold local licences, while telecoms require national networks. Thus, individual spectrum licences are only valuable for exchange if they can be assembled together into regional networks. ${ }^{21}$ But if a telecom company were to contract sequentially with individual broadcasters, it could face an exposure problem: if the telecom could not buy the last spectrum licence needed for its network, all the licences already purchased would be worth less.

The exposure problem amplifies broadcasters' incentive to 'hold out' for high prices. If the government cannot coerce stations to surrender their licences, then each station might attempt to claim a large share of the telecoms' surplus; if many complementary licences must be assembled, the probability of efficient trade then becomes vanishingly small (Cournot, 1838; Bergstrom, 1978; Mailath and Postlewaite, 1990). However, the theoretical inefficiency can be at least partially mitigated by the practical possibility of 'repacking' spectrum across bandwidths: if instead of needing to purchase specific stations (e.g. all the stations occupying a particular frequency nationwide), telecom companies could make do with just a specific number of stations, then efficient trade is much more likely to succeed (Kominers and Weyl, 2012; Rosston, 2012).

\section{The solution}

Working with the US Federal Communications Commission (FCC), a team of economists and computer scientists developed a two-sided spectrum auction that became

20 The spectrum auctions in the US and the UK have respectively been called 'the greatest auction in history' (McAfee et al., 2010) and 'the biggest auction ever' (Binmore and Klemperer, 2002).

21 We also need unused 'guard bands', which serve as buffers that prevent television broadcasters from interfering with mobile operators. 
known as the 'Incentive Auction' (Leyton-Brown et al., 2017; Milgrom, 2017; Milgrom and Segal, 2017).

The telecoms' exposure problem was addressed by running a 'forward' ascending clock auction that allowed telecom companies to bid on licences as packages. The holdout problem was mitigated in two ways. First, the government made a regulatory determination that while none of the almost 3,000 television stations could be forced to give up their broadcasting rights, they could be reassigned to other frequencies as long as the reassignment did not subject them to significant interference from neighbouring stations. The idea was to reduce the complementarity of stations from the perspective of telecom companies - exactly the 'repacking' scenario described in the preceding section. Second, instead of asking television broadcasters to declare prices for their spectrum licences directly, the FCC ran a descending clock 'reverse' auction for broadcasters' licences. All stations were made initial buyback price offers, and then those offers were slowly reduced. Each time a station's price was reduced, that station chose whether to remain in the auction or exit irreversibly. As long as a station remained in, its licence could be bought at the current offer price. Before any given station's price was lowered, an advanced feasibility-checking algorithm (Newman et al., forthcoming) would check whether that station could be reassigned in an (almost) interference-free way if it were to exit; ${ }^{22}$ the price offer would be lowered if an interference-free repacking could be found; and the price would be 'frozen' (i.e. held fixed) otherwise.

The descending auction format made bidding particularly simple for the broadcasters: at each moment, every broadcaster effectively faced a 'take-it-or-leave-it' price offer. At each point in the auction, there was always some chance that all the broadcasters who remained in the auction would end up selling at their prevailing offer prices. Thus, whenever a broadcaster's offer price was above that broadcaster's private value of operating a television station, the optimal strategy was to remain in the auction, for a chance of making a profit. Likewise, it was optimal for broadcasters to exit the auction as soon as their offer prices fell below their private values (Milgrom and Segal, 2017; Li, forthcoming). The simplicity of the reverse auction's design was particularly crucial for ensuring the participation of smaller stations.

Meanwhile, the full set of interference constraints turned out to be incredibly complex. Indeed, figuring out whether an interference-free reassignment exists at any clock price is a computationally intractable problem. Computer scientists worked closely with economists to develop cutting-edge feasibility checkers that could find solutions as quickly and accurately as possible between the ticks of the auction clock (Newman et al., forthcoming). ${ }^{23}$

The interference constraints also meant that the FCC could only reallocate spectrum once it knew exactly how much spectrum could be feasibly reallocated. For that reason, the Incentive Auction iterated in stages between rounds of the reverse auction that determined the supply of licences and rounds of the forward auction that determined the demand for licence packages. At each iteration, the FCC lowered the target amount

22 The feasibility constraint required that each neighbouring station cause no more than 0.5 per cent interference to the affected station's served population.

${ }^{23}$ The complexity and the competitive nature of reassignment may have additionally reduced stations' incentives to hold out. 
of spectrum to be reallocated ${ }^{24}$ until it could ensure that the revenue from the forward auction fully covered the costs from the reverse auction. ${ }^{25}$

The bidding in the Incentive Auction ran from May 2016 to March 2017. In the end, $84 \mathrm{MHz}$ of spectrum was transferred from television stations to telecom companies for mobile broadband and consumer devices (reassigning channels 38-51, corresponding to the $614-698 \mathrm{MHz}$ range). The process also generated substantial revenue for the government: the telecom companies paid $\$ 19$ billion in the forward auction, while television stations received $\$ 10$ billion in the reverse auction, netting the US Treasury over $\$ 7$ billion after administrative and post-auction repacking costs.

Rules: Iterative (forward-reverse) double auction with package bidding.

Infrastructure: Regulations and technology supporting spectrum repacking; electronic auction platform; feasibility checking algorithms.

\section{Related applications}

Single-item auctions are ubiquitous, of course, but simple package auctions have also been used for a long time. There are now dozens of varieties of combinatorial auctions (Parkes and Ungar, 2000; Parkes et al., 2001; Cramton et al., 2006; Milgrom, 2007; Mishra and Parkes, 2007; Day and Milgrom, 2008; Erdil and Klemperer, 2010; Day and Cramton, 2012; Levin and Skrzypacz, 2016) that vary in their numbers of sellers (one or many), bidding languages (e.g. allowing bidders to express whether they are willing to win multiple packages or not), extensive form (sealed-bid or dynamic), price-adjustment procedures (monotonic or non-monotonic), price structures (linear or nonlinear; anonymous or non-anonymous), and outcomes (e.g. coreselecting or Vickrey (1961)). ${ }^{26}$ Moreover, combinatorial auctions are popular not just for spectrum allocation (Ausubel and Baranov, 2014; Cramton and Ockenfels, forthcoming), but also for diverse applications including truckload transportation (Sheffi, 2004), school meals (Olivares et al., 2012), and London bus routes (Cantillon and Pesendorfer, 2006).

Computationally complex constraints on market clearing also arise in a range of contexts (Milgrom, 2017). Competitive electricity markets such as ERCOT (Cramton, 2017), for example, need to clear at every point in time in order to avoid blackouts. However, to clear electricity markets, system operators need to continuously solve difficult integer optimization problems because of grid congestion and infrastructure constraints involving start-up timing of individual generators.

24 Uniform clearing of spectrum was desirable, as any alternative would create costly inter-service interference; hence, the designers chose to iterate through a sequence of overall clearing targets.

25 The revenue from the forward auction exceeded the costs of the reverse auction (plus a surplus target) after four stages.

26 In addition to new theory, the design of complex package auctions often requires extensive experimental testing in the lab (Brunner et al., 2010; Y. Chen and Takeuchi, 2010; Goeree and Holt, 2010; Kagel et al., 2010, 2014; Scheffel et al., 2011; Chernomaz and Levin, 2012; Bichler et al., 2013; Marszalec, 2016). 


\section{Some key tenets}

The market design solutions described in the preceding section draw upon rigorous economic theory, as well as ideas from computer science and operations research. Our examples illustrate how well-designed marketplace rules and infrastructure can:

- encourage participation,

- making doctors and hospitals willing to join a single, centralized residency market,

- enabling small food banks to partner and bid jointly, and

- reducing telecom companies' exposure problems through package bidding;

- reduce strategic gaming,

- incentivizing doctors to report their true preferences over hospitals,

- removing food banks' incentives to accept unwanted food donations, and

- preventing television broadcasters from holding out for monopoly rents; and

- aggregate information,

- collecting doctors' and hospitals' preferences into a single system,

- determining relative demand for different food donation types through scrip prices, and

- discovering market-clearing prices for many heterogeneous spectrum licences.

Improving market function along the lines just described allows the designer to achieve a number of important objectives:

- efficiency,

- improving the quality of job-candidate matches in medical residency programmes,

- enabling demand differentiation in food allocation, and

- ensuring that spectrum licences are held by the firms that value them the most;

- liquidity,

- assigning as many doctors as possible, and filling as many residency positions as possible,

- placing almost every food donation, and thus reducing the number of donations that are wasted, and

- ensuring that telecoms can assemble swathes of spectrum licences from a range of potential sellers; and

- equity,

- making sure that no doctors miss out on residency positions for which they are preferred to accepted candidates,

- redistributing scrip paid in each food donation auction, so that small food banks can benefit even from the auctions they do not win, and

- ensuring that the public purse can benefit from the revenue raised in spectrum licence reallocation. 
The principles just described have already been identified in different marketplaces such as auctions, two-sided platforms, and matching clearinghouses (Klemperer, 2002; Eisenmann et al., 2006; A. E. Roth, 2008b). ${ }^{27}$

However, while the underlying principles are often consistent across market design applications, it is important to observe that achieving similar design objectives in our three examples required substantially different choices of rules and infrastructure. The articles in this issue further highlight how different market contexts require different design solutions. In school choice and in kidney exchange, for example, there are social and legal constraints on the ability of the designer to use any form of currency - even scrip (Cantillon, 2017; Sönmez and Ünver, 2017). In electricity, financial, and permit markets, the designer is faced with a dynamic setting, and needs to ensure that market clearing can take place continuously (Cramton, 2017; Kyle and J. Lee, 2017; Schmalensee and Stavins, 2017).

Additionally, it is essential to recognize that there are often fundamental trade-offs among market design objectives. In auctions, for example, a designer typically trades off revenue against efficiency (Wilson, 1979; Myerson, 1981). In school choice, it is usually impossible to achieve Pareto-efficient outcomes for students while simultaneously guaranteeing that no student's priority is violated (Abdulkadiroğlu and Sönmez, 2003; Kesten, 2010; Cantillon, 2017). In kidney exchange, meanwhile, efficiency is constrained because the logistical costs of running simultaneous operations prevent doctors from conducting kidney exchanges across many pairs of patients at once (A. E. Roth, 2008b; Sönmez and Ünver, 2017). And online or digital marketplace organizers often use simple mechanisms to encourage participation and reduce cognitive burden ('rate from 1 to 5 stars', 'swipe left'), even though such mechanisms limit full preference elicitation (Milgrom, 2010; Budish et al., 2016; Edelman, 2017).

Successful market design solutions are bound to vary across markets because realworld settings have distinct (and sometimes unexpected) objectives, constraints, and trade-offs. It would be odd, for example, to ask broadcasters to trade spectrum for scrip, or for us to sell residencies (or donated food) to the highest cash bidders, or ask users to submit full preference rankings on dating websites. There is no one-size-fits-all market design.

\section{New marketplaces in areas of public policy}

Next, we highlight several areas of public policy that could benefit from improved market design. Our list is far from exhaustive, but we hope it will nevertheless serve to stimulate new theoretical inquiries and practical solutions.

\footnotetext{
27 Klemperer (2002) argued that 'what really matters in auction design' is reducing entry deterrence (encouraging participation) and preventing collusion (reducing strategic gaming). Eisenmann et al. (2006) offered three challenges for two-sided platforms: getting pricing right, coping with winner-takes-all competition, and managing overlapping user-bases (all of which relate to encouraging participation). A. E. Roth (2008b) identified thickness (encouraging participation), managed congestion (aggregating information), and safety to reveal preferences (reducing strategic gaming) as key features of successful matching marketplaces.
} 


\section{(i) Digital markets}

Online marketplaces have evolved from simple auction platforms (e.g. eBay), to largescale sponsored search auctions (Edelman et al., 2007; Varian, 2007; Agarwal et al., 2009; Athey and Nekipelov, 2010; Athey and Ellison, 2011), to the sophisticated realtime pricing and matching infrastructure used in the sharing economy (e.g. ride-sharing apps such as Lyft and Uber (Azevedo and Weyl, 2016; P. Cohen et al., 2016; Cramer and Krueger, 2016; J. V. Hall and Krueger, 2016; Castillo et al., 2017; M. K. Chen et al., 2017), as well as short-term rental platforms such as Airbnb (Fradkin et al., 2017; Zervas et al., forthcoming)). Online platforms must fight many of the same battles faced in offline market design. ${ }^{28}$ However, as Edelman (2017) points out, online settings introduce many new market design challenges.

One key problem is trust and anonymity. Why should I allow a complete stranger into my car, much less my home? How do I know that an online retailer will not misrepresent quality (and will actually ship my purchases)? Many online marketplaces overcome trust problems by creating review and reputation systems, but those systems can often be vulnerable to abuse and misrepresentation (Luca, 2016; Tadelis, 2016; Edelman, 2017; Fradkin et al., 2017).

Another issue involves data ownership and privacy. Online behaviour generates vast quantities of data, sometimes called 'digital exhaust' (Luca, forthcoming); these data are increasingly valuable to advertisers and companies, who can mine them for use in developing and targeting new products. But currently, consumers have little control over how their data are used and distributed. Moreover, the value consumers place on privacy is unclear (Athey et al., 2017a). We might imagine that in the future, individuals would receive a share of the value their data generates, perhaps by renting access in exchange for micro-payments; one market design approach draws upon 'differential privacy', which allows data sharing while minimizing private data leakage (Dwork, 2011; A. Roth and Schoenebeck, 2012; Dwork and A. Roth, 2014; Ghosh et al., 2014; Ghosh and A. Roth, 2015).

It is also worth noting that data privacy rules themselves have distributional consequences. Removing the ability of sellers to personalize prices (e.g. based on browser use, geography, and prior browsing history) forces merchants to price towards the middle of the distribution - and thus can often lead to price increases for consumers with the least ability to pay (Goldfarb and Tucker, 2011). Restrictions on data sharing can also prevent crucial information aggregation-for example, restrictions on the sharing of electronic medical records have been shown to lead to increased neonatal mortality (A. R. Miller and Tucker, 2011).

\section{(ii) Living-donor organ allocation}

Thousands of people around the world are on dialysis and require kidney transplants in order to be able to lead healthy lives. However, commercial exchange of kidneys is

28 For example, both online and offline platforms often struggle to generate initial participation and liquidity (Rochet and Tirole, 2003, 2006; Armstrong, 2006; Eisenmann et al., 2006; Weyl, 2010; Eisenmann and Kominers, 2017; Fradkin, forthcoming). 
prohibited in almost every country in the world. Many patients have friends or relatives who are willing to donate kidneys to them, but some of those prospective donors are unable to donate because of blood- or tissue-type mismatches.

If patient $A$ has an incompatible donor $A^{\prime}$ and patient $B$ has an incompatible donor $B^{\prime}$, it is sometimes the case that $B^{\prime}$ is compatible with $A$, and $A^{\prime}$ is compatible with $B$-so in principle, $A$ and $B$ can 'swap' donors. To enable patients to swap donors at scale, market designers have organized centralized kidney exchanges. Because it is not possible to contract over kidneys, early kidney exchanges required substantial logistical infrastructure - multiple simultaneous surgeries - so as to ensure that each exchange could be completed entirely at once (A. E. Roth et al., 2004, 2005a, b, 2007). Nowadays, many kidney exchanges are conducted in chains, whereby an altruistic, non-directed donor $A^{\prime}$ donates to a patient $B$ with an incompatible but willing donor $B^{\prime}$, and $B^{\prime}$ ' then 'pays it forward' by donating to another patient $C$ in the future. If $C$ has an incompatible but willing donor $C^{\prime}$, then $C^{\prime}$ can donate in the future, and so forth, eventually leading to a long sequence of kidney exchanges over a period of years (Rees et al., 2009; Ashlagi et al., 2011, 2012; Anderson et al., 2015).

The success of kidney exchange in many countries has led market designers to explore further opportunities for saving lives through organ exchange.

One new possibility is international exchanges (Rees et al., 2017). Dialysis costs are so high that healthcare providers in affluent countries may be able to save money overall by enabling their patients with willing but incompatible kidney donors to exchange kidneys with patient-donor pairs from other countries. In an international kidney exchange, the affluent country's healthcare provider would cover all of the costs for the international donor and patient, including post-surgical and ongoing treatment; amazingly, this is still less expensive than long-term dialysis (Nikzad et al., 2017). The resulting welfare benefits can be substantial not only because of the lives saved, but also because of patients from poorer countries' getting access to world-class healthcare, and because of overall cost savings in richer countries.

A second frontier involves exchanges of organs beyond kidneys: lungs and livers (Sönmez and Ünver, 2017; Ergin et al., forthcoming). Lung exchange in particular may have enormous life-saving potential (Ergin et al., 2014). Taken to a logical extreme, we could even conceive of multi-organ exchanges in which a patient who needs a kidney can enter into an exchange with a donor who is willing to donate a kidney or a lung. ${ }^{29}$ A crucial part of the success of many organ exchanges will be encouraging new donors to participate (Sunstein and Thaler, 2003; Kessler and A. E. Roth, 2012, 2014).

\section{(iii) Financial markets}

Trillions of dollars' worth of financial instruments, including equity shares, bonds, and derivatives, are traded across the world every day. A rich finance literature has examined how market microstructure affects the performance of financial markets (O'Hara, 1995; Madhavan, 2000; Biais et al., 2005).

Many securities are traded via continuous limit order books that aggregate bids and asks into a central, publicly observed ledger. We often think of continuous limit order

29 While the infrastructure for such marketplaces is not yet ready, the requisite theoretical frameworks are already being developed (Dickerson and Sandholm, 2014). 
books as essentially equivalent to the competitive market ideal of running in perfectly continuous time. However, at microsecond intervals, limit order books can be surprisingly illiquid and uncompetitive; this creates incentives for high-frequency traders to invest in costly technology for arbitraging across different exchanges at the expense of slower traders, such as pension funds (Biais et al., 2015).

One attractive response to excessive high-frequency trading, proposed by Budish et al. (2015), is to change the market clearing rules so all exchanges run discrete auctions (see also Budish et al. (2017) and Melton (2017)). Under frequent, discrete batch auctions, all orders received in each small time interval are treated equally, encouraging price rather than speed competition and reducing the incentive to place an order 'first'. ${ }^{30}$ An infrastructure solution, proposed by Kyle and J. Lee (2017), is to allow limit orders to be continuous not only in price and quantity, but also in time; that way, large trades could be spread over time and 'flow' continuously into the exchange. Both the Budish et al. (2015) and Kyle and J. Lee (2017) approaches could remove the 'first-to-act' advantages that high-frequency traders currently enjoy.

Meanwhile, a vast number of financial market transactions (e.g. for corporate bonds, mortgage-backed securities, and exotic derivatives) occur in over-the-counter markets, in which prices are not quoted publicly, and are instead settled through bilateral negotiations (Duffie et al., 2005; Zhu, 2011). Because bilateral offers can expire as soon as they are announced, participants often face high search costs - and can thus be exposed to unfavourable sets of transactions. Future work could investigate how to increase liquidity and improve coordination and efficiency in over-the-counter markets.

\section{(iv) Refugee resettlement}

The recent refugee crisis precipitated by conflict in Syria has pushed the number of forcibly displaced people around the world to $65 \mathrm{~m}$, creating over $16 \mathrm{~m}$ refugees (United Nations High Commissioner for Refugees, 2017). Many EU countries were unprepared for the large number of refugees that have arrived since 2015, and the EU has struggled to find a system that would both fairly compensate those places that accept refugees and encourage other states to welcome more.

One macro-level proposal suggests combining country-level tradable refugee admission quotas with a matching system that allows refugees to express preferences over destination countries (Moraga and Rapoport, 2014). A more micro area in which market design can play a role is within-country resettlement. There is abundant evidence that the local areas to which refugees are resettled have strong impacts on refugees' economic outcomes (Åslund and Rooth, 2007; Åslund et al., 2011)-yet refugees are typically not consulted about where they would prefer to be resettled.

Andersson and Ehlers (2016) have proposed a way to match refugees to housing in Sweden on the basis of family size and language compatibility. Meanwhile, Jones and Teytelboym (forthcoming) and Delacrétaz et al. (2016) have respectively proposed infrastructure and rules for a matching system that allows both local areas and refugees

${ }^{30}$ Discrete batch auctions could increase the exposure of traders who want to buy and sell different shares at the same time. Instead of running a separate auction for every share, one could trade many shares in each auction; such 'product-mix' auctions would allow traders to place limit orders on several shares simultaneously (Klemperer, 2010). 
to express preferences over possible matches. ${ }^{31}$ Future research could combine refugee matching frameworks with financing mechanisms.

\section{(v) Natural ecosystems}

Resource-intensive economic growth over the past three centuries has taken a toll on the stock of renewable natural capital. Rainforests are being decimated (Hansen et al., 2013), fish stocks are declining (Worm et al., 2009), biodiversity is disappearing (Cardinale et al., 2012; Dirzo et al., 2014), and the atmosphere is filling with anthropogenic carbon, causing dramatic changes in climate (Allen et al., 2009). ${ }^{32}$

Many environmental externalities have been partially addressed via permit trading in the spirit of classic Pigouvian solutions (Montgomery, 1972). Environmental marketplace design often focuses on settings in which natural resources are to some extent substitutable: a ton of carbon emissions, for example, affects the atmosphere no matter where it comes from; one cod left in the sea will support the population as well as another cod. Following the success of sulphur dioxide permit trading to reduce acid rain in the US, the European Union led the world in setting up a carbon dioxide permit trading system (Schmalensee and Stavins, 2017). Meanwhile, many countries use individual tradable quotas (ITQs) to allocate fishing rights (Chu, 2009; Stavins, 2011; Bjørndal and Munro, 2012). ${ }^{33}$ Although many other innovative ecosystem market designs - payments for ecosystem services, wetland offset trading, and water quality permit trading - already exist in practice (Stoneham et al., 2003; Bishop and Pagiola, 2012; Shortle and Horan, 2013; Jayachandran et al., 2017), they have either failed to scale or have been controversial (Robertson and Hayden, 2008; Kinzig et al., 2011; Muradian et al., 2013).

Most natural ecosystems feature complementarities (Helm and Hepburn, 2012): trees need soil to grow, and soil requires tree roots to prevent it from being washed away; bees need flowers for nectar, and flowers need bees to pollinate them; cod often breed alongside haddock. ${ }^{34}$ However, the associated property rights are often allocated in ways that ignore natural capital's underlying complementarities and interdependencies. Thus (terrestrial) ecosystem protection faces similar problems of exposure and holdout to those that were tackled by the Incentive Auction: investors want to conserve large swathes of adjacent land, but this gives landowners substantial bargaining power (Nemes et al., 2008; Iftekhar et al., 2012). Marketplaces for ecosystem services are further complicated by issues of investment timing: landowners are typically paid after they have maintained or conserved their land. If a landowner is paid to protect his meadow, but a nearby farmer pollutes an

31 The proposed system is similar to existing systems for school choice (Cantillon, 2017), except it takes into account the fact that refugees typically arrive in families and require a number of different public services, such as housing, school places, and language or employment training - inducing combinatorial constraints similar to those encountered in course allocation and the Incentive Auction.

32 On the other hand, there is almost no evidence that non-renewable natural capital (mainly commodities and minerals that are traded on exchanges at market prices) is becoming more scarce (Hepburn et al., 2017).

${ }^{33}$ However, very few countries use auctions to allocate fishing quota (Tisdell and Iftekhar, 2013; Marszalec, forthcoming).

34 This complementarity is compounded by the fact that much natural capital is critical: degrading it beyond a certain point causes irreversible collapse of ecosystems (Ekins et al., 2003). 
adjacent river - contaminating the whole ecosystem - then the efforts of the landowner go to waste. If it is not possible to make payments contingent on the outcome of the whole ecosystem, then the designer might end up over- or under-compensating landowners. Moreover, if designers want to incentivize land improvements, then they also need to tackle ex ante moral hazard problems, as otherwise landowners would have incentives to degrade their land in order to be paid to improve it (Ferraro, 2008).

Nevertheless, advances in satellite technology and data processing are dramatically reducing the costs of monitoring land-use change, and could possibly allow ecosystem services marketplace infrastructure to be created at large scales (see, for example, NaturEtrade, a digital marketplace for ecosystem investment that uses satellite data to track ecosystem function).

\section{(vi) Road and air transport}

Traffic congestion is a classic externality problem that creates large welfare losses (Vickrey, 1969), and its management is becoming more effective because of technological advances (Cramton et al., 2017). Singapore, London, and many other cities around the world have developed sophisticated infrastructure for pricing access to city centres (Santos, 2005; Leape, 2006). The received wisdom has been that congestion pricing must create both winners and losers - there will always be those who cannot afford to pay and therefore are not able to travel. However, the conventional view that congestion pricing is only redistributive is now being challenged. If congestion not only lengthens traffic queues but also reduces throughput, then congestion pricing can eliminate bottlenecks and thus be Pareto-improving without the need for compensation (J. D. Hall, 2017).

In parallel, ride-sharing companies such as Lyft and Uber have used smartphonebased networks to supplant classical taxi technologies, by allowing customers to request rides from non-professional drivers at prices that reflect local supply and demand conditions (Cramer and Krueger, 2016). In the future, driverless cars will offer even greater possibilities for innovative ride-sharing marketplace designs that could combine individual and public transport.

Air transport also creates interesting market design possibilities. While academics have long promoted auctioning airport landing and take-off slots (Rassenti et al., 1982; Schummer and Vohra, 2013; Schummer and Abizada, 2017), there has been substantial resistance from industry (Sentance, 2003). Yet the difficulties of expanding airports in urban areas mean that efficient allocation of slots must soon become a priority. ${ }^{35}$ Moreover, the increases in drone, satellite, and rocket launches will create important new problems in the coming decade: combined allocation of horizontal and vertical air traffic rights (Milgrom, 2017), as well as allocation of orbit rights.

\section{(vii) Intellectual property}

In recent years, there has been a sharp increase in patent lawsuits in the US, predominantly driven by non-practising entities (NPEs), firms that amass patents just for the sake of enforcing intellectual property rights through licensing and litigation (rather than producing commercial products). A growing body of evidence (see, for example, L. Cohen

35 On 21 July 2017, 8,800 aircraft passed through UK airspace- the largest number ever. 
et al. (2017a) and the references therein) suggests that NPEs on average act as patent trolls, pursuing opportunistic litigation (L. Cohen et al., 2016, 2017b), shopping for favourable forums (Leychkis, 2007; L. Cohen et al., 2016), and often asserting low-quality patents (Love, 2013; S. P. Miller, 2013; Feng and Jaravel, 2015; Allison et al., forthcoming). Yet because litigation outcomes are uncertain and most of the upfront discovery costs in patent litigation fall on defendants, credible threat of the legal process is often sufficient to induce firms targeted by NPEs to settle, irrespective of lawsuit quality.

NPE litigation imposes significant costs on defendants (Bessen et al., 2011; Bessen and Meurer, 2014), and reduces research and development efforts (Tucker, 2014; L. Cohen et al., 2017b), start-up financing (Chien, 2014; Kiebzak et al., 2016), and small business employment (Appel et al., 2016). Meanwhile, even though NPEs bill themselves as encouraging innovation by strengthening the patent system, NPE litigation activity does not appear to be associated to increases in invention (L. Cohen et al., 2015, 2017b).

The 2011 America Invents Act placed some limitations on patent lawsuits and introduced a procedure by which third parties can challenge the validity of individual patents through a specialized government body called the Patent Trial and Appeal Board. Further legislative patent reforms have been considered by the US Congress, but have stalled thus far. Moreover, most of the recent policy discussions have focused on rules imposing ex post cost shifting - plaintiffs that lose patent lawsuits would be required to pay defendants' legal fees, as they are in the UK and elsewhere (Helmers et al., 2013; Love et al., 2017).

Because many defendants (e.g. small start-ups) cannot afford to see cases through to completion, it is not clear how much fee-shifting policies will affect outcomes (Klemperer, 2003). An alternative strategy for the redesign of the intellectual property litigation marketplace is to impose upfront screening rules: L. Cohen, Golden, Gurun, and Kominers (forthcoming) propose a system whereby all patent lawsuits would be preceded by a brief administrative review that provides a preliminary assessment of lawsuit quality. The review process would assess the quality of each plaintiff's patents and infringement claims; these findings would be non-binding, but would be advisory in court proceedings and could be used to calibrate fee shifting and penalty rules. In extreme cases, the review process could even trigger re-examination of the asserted patents. If implemented correctly, preliminary review rules could substantially reduce incentives of NPEs to game the litigation system with frivolous lawsuits, while potentially bolstering the cases of plaintiffs with legitimate infringement claims.

\section{Outlook}

As market design becomes a more familiar part of practitioners' and policy-makers' toolkits, its applications will extend far beyond the contexts we have described here. Today, market design is beginning to operate in the presence of:

- reduced costs of communication and coordination across space and time (Moore, 1965),

- vast data sets (Einav and Levin, 2014; Athey, 2017a,b), including digitized media (books, maps, and historical archives), information about social networks (Pentland, 2014), and high-resolution imagery data (Naik et al., 2017; Glaeser et al., forthcoming), 
- a richer understanding of strategic behaviour and psychology (Crawford and Iriberri, 2007; Crawford et al., 2009; Kôszegi, 2014; Crawford, 2016; Li, forthcoming), and

- increased use of artificial intelligence (Parkes and Wellman, 2015; Kearns, 2017; Milgrom and Tadelis, 2017; Mullainathan and Obermeyer, 2017).

At the same time, market design is coming to interact more closely with the rest of economics and economic policy. We are, for example, beginning to understand how school choice systems interact with policies designed to improve school quality and composition (Calsamiglia and Miralles, 2016; Hatfield, Kojima, and Narita 2016; Cantillon, 2017; Avery and Pathak, forthcoming), how the allocation of land rights can improve agricultural productivity and investment in human capital (Bryan et al., 2017; Glaeser and Kominers, forthcoming), and how auctions can reduce corruption in public procurement (Tran, 2009; Lewis-Faupel et al., 2016). Perhaps one of the greatest challenges for market design will come from problems in developing markets, where weak institutions necessitate new design approaches (Banerjee and Duflo, 2011; B. N. Roth, forthcoming).

It is essential that market design not be divorced from broader political and economic policy issues such as inequality (Atkinson, 2015), globalization (Baldwin, 2016), and migration (Clements, 2018). And market designers should not work only within the boundaries of circumscribed marketplaces: the design of healthcare programmes should reflect priorities in health policy; the design of financial exchanges should be linked to debates on financial regulation; and electricity market design should play a key role in the transition to a decarbonized economy.

The examples in this paper and the articles in this issue highlight many successes of market design and avenues for future work. Yet just as economics is a way of thinking about the world, market design is a way of thinking about economics. Thus, we hope and expect that market design approaches will prove valuable throughout economic policy - far beyond the applications we can imagine today.

\section{References}

Abdulkadiroğlu, A. (2005), 'College Admissions with Affirmative Action', International Journal of Game Theory, 33(4), 535-49.

- Sönmez, T. (2003), 'School Choice: A Mechanism Design Approach', American Economic Review, 93(3), 729-47.

- Pathak, P. A., and Roth, A. E. (2005a), 'The New York City High School Match', American Economic Review, 95(2), 364-7.

— - - Sönmez, T. (2005b), 'The Boston Public School Match', American Economic Review, 95(2), 368-71.

Acemoğlu, D., Johnson, S., and Robinson, J. A. (2001), 'The Colonial Origins of Comparative Development: An Empirical Investigation', American Economic Review, 91(5), 1369-401.

Agarwal, N., Athey, S., and Yang, D. (2009), 'Skewed Bidding in Pay-per-action Auctions for Online Advertising', American Economic Review, 99(2), 441-7.

Akerlof, G. A. (1970), 'The Market for “Lemons”: Quality Uncertainty and the Market Mechanism', Quarterly Journal of Economics, 84(3), 488-500.

Alberola, E., Chevallier, J., and Chèze, B. (2008), 'Price Drivers and Structural Breaks in European Carbon Prices 2005-2007', Energy Policy, 36(2), 787-97. 
Allen, M. R., Frame, D. J., Huntingford, C., Jones, C. D., Lowe, J. A., Meinshausen, M., and Meinshausen, N. (2009), 'Warming Caused by Cumulative Carbon Emissions Towards the Trillionth Tonne', Nature, 458(7242), 1163-6.

Allison, J. R., Lemley, M. A., and Schwartz, D. L. (forthcoming), 'How Often Do Patent Assertion Entities Win Patent Suits?', Berkeley Technology Law Journal.

Anderson, R., Ashlagi, I., Gamarnik, D., and Roth, A. E. (2015), 'Finding Long Chains in Kidney Exchange Using the Traveling Salesman Problem', Proceedings of the National Academy of Sciences, 112(3), 663-8.

Andersson, T., and Ehlers, L. (2016), 'Assigning Refugees to Landlords in Sweden: Stable Maximum Matchings', Lund University Working Paper.

Appel, I., Farre-Mensa, J., and Simintzi, E. (2016), 'Patent Trolls and Small Business Employment', Harvard University Working Paper.

Armstrong, M. (2006), 'Competition in Two-sided Markets', RAND Journal of Economics, 37(3), 668-91.

Arrow, K. J. (1964), 'The Role of Securities in the Optimal Allocation of Risk-bearing', Review of Economic Studies, 31(2), 91-6.

- Debreu, G. (1954), 'Existence of an Equilibrium for a Competitive Economy', Econometrica, 22(3), 265-90.

Ashlagi, I., Braverman, M., and Hassidim, A. (2014), 'Stability in Large Matching Markets with Complementarities', Operations Research, 62(4), 713-32.

- Gamarnik, D., Rees, M., and Roth, A. E. (2012), 'The Need for (Long) Chains in Kidney Exchange', NBER Working Paper No. 18202.

- Gilchrist, D. S., Roth, A. E., and Rees, M. A. (2011), 'NEAD Chains in Transplantation', American Journal of Transplantation, 11(12), 2780-1.

Åslund, O., and Rooth, D.-O. (2007), 'Do When and Where Matter? Initial Labour Market Conditions and Immigrant Earnings', The Economic Journal, 117(518), 422-48.

- Edin, P.-A., Fredriksson, P., and Grönqvist, H. (2011), 'Peers, Neighborhoods, and Immigrant Student Achievement: Evidence from a Placement Policy', American Economic Journal: Applied Economics, 3(2), 67-95.

Athey, S. (2017a), 'Beyond Prediction: Using Big Data for Policy Problems', Science, 355(6324), 483-5.

- (2017b), 'The Impact of Machine Learning on Economics', Stanford University Working Paper.

- Ellison, G. (2011), 'Position Auctions with Consumer Search', Quarterly Journal of Economics, 126(3), 1213-70.

- Nekipelov, D. (2010), 'A Structural Model of Sponsored Search Advertising Auctions', Stanford University Working Paper.

- Catalini, C., and Tucker, C. (2017), 'The Digital Privacy Paradox: Small Money, Small Costs, Small Talk', NBER Working Paper No. 23488.

Atkinson, A. B. (2015), Inequality: What Can Be Done?, Cambridge, MA, Harvard University Press.

Ausubel, L. M., and Baranov, O. V. (2014), 'Market Design and the Evolution of the Combinatorial Clock Auction', American Economic Review, 104(5), 446-51.

Avery, C., and Pathak, P. A. (forthcoming), 'Missing "One-offs" in High School Choice in New York City', in S. D. Kominers and A. Teytelboym (eds), Fair by Design: Economic Design Approaches to Inequality, Oxford, Oxford University Press.

- Jolls, C., Posner, R. A., and Roth, A. E. (2001), 'The Market for Federal Judicial Law Clerks', University of Chicago Law Review, 68(3), 793-902.

_ _ _ _ (2007), 'The New Market for Federal Judicial Law Clerks', University of Chicago Law Review, 74(2), 447-86.

Aygün, O., and Bó, I. (2016), 'College Admission with Multidimensional Privileges: The Brazilian Affirmative Action Case', WZB Berlin Social Science Center Working Paper.

- Turhan, B. (2017), 'Large-scale Affirmative Action in School Choice: Admissions to IITs in India', American Economic Review, 107(5), 210-13.

Azevedo, E. M., and Hatfield, J. W. (2015), 'Existence of Stable Matchings in Large Markets with Complementarities', University of Texas at Austin Working Paper.

- Weyl, E. G. (2016), 'Matching Markets in the Digital Age', Science, 352(6289), 1056-7. 
Azevedo, E. M., Weyl, E. G., and White, A. (2013), 'Walrasian Equilibrium in Large, Quasilinear Markets', Theoretical Economics, 8(2), 281-90.

Baldwin, R. (2016), The Great Convergence, Cambridge, MA, Harvard University Press.

Bandyopadhyay, S., Ishakov, F., Johnson, T., Lee, S., McArthur, D., Rust, J., Watson, J., and Watson, J. (2013), 'Can the Job Market for Economists Be Improved?', in N. Vulkan, A. E. Roth, and Z. Neeman (eds), The Handbook of Market Design, Oxford, Oxford University Press, 189-221.

Banerjee, A. V., and Duflo, E. (2011), Poor Economics: A Radical Rethinking of the Way to Fight Global Poverty, PublicAffairs.

Bergstrom, T. C. (1978), 'Cournot Equilibrium in Factor Markets', UCSB Working Paper.

Bessen, J. E., and Meurer, M. J. (2014), 'The Direct Costs from NPE Disputes', Cornell Law Review, 99(2), 387-424.

- - Ford, J. (2011), 'The Private and Social Costs of Patent Trolls', Regulation, 34(4), 26-35.

Biais, B., Foucault, T., and Moinas, S. (2015), 'Equilibrium Fast Trading', Journal of Financial Economics, 116(2), 292-313.

- Glosten, L., and Spatt, C. (2005), 'Market Microstructure: A Survey of Microfoundations, Empirical Results, and Policy Implications', Journal of Financial Markets, 8(2), 217-64.

Bichler, M., Shabalin, P., and Wolf, J. (2013), 'Do Core-selecting Combinatorial Clock Auctions Always Lead to High Efficiency? An Experimental Analysis of Spectrum Auction Designs', Experimental Economics, 16(4), 511-45.

Binmore, K., and Klemperer, P. (2002), 'The Biggest Auction Ever: The Sale of the British 3G Telecom Licences', The Economic Journal, 112(478).

Biró, P., and Klijn, F. (2013), 'Matching with Couples: A Multidisciplinary Survey', International Game Theory Review, 15(02), 1340008.

Bishop, J., and Pagiola, S. (2012), Selling Forest Environmental Services: Market-Based Mechanisms for Conservation and Development, Taylor \& Francis.

Bjørndal, T., and Munro, G. (2012), The Economics and Management of World Fisheries, Oxford, Oxford University Press.

Bogomolnaia, A., and Moulin, H. (2001), 'A New Solution to the Random Assignment Problem', Journal of Economic Theory, 100(2), 295-328.

Brunner, C., Goeree, J. K., Holt, C. A., and Ledyard, J. O. (2010), 'An Experimental Test of Flexible Combinatorial Spectrum Auction Formats', American Economic Journal: Microeconomics, 2(1), $39-57$.

Bryan, G., de Quidt, J., Wilkening, T., and Yadav, N. (2017), 'Land Trade and Development: A Market Design Approach', CESifo Working Paper No. 6557.

Budish, E. (2011), 'The Combinatorial Assignment Problem: Approximate Competitive Equilibrium from Equal Incomes', Journal of Political Economy, 119(6), 1061-103.

- Cantillon, E. (2012), 'The Multi-unit Assignment Problem: Theory and Evidence from Course Allocation at Harvard', American Economic Review, 102(5), 2237-71.

- Kessler, J. B. (2016), 'Bringing Real Market Participants' Real Preferences into the Lab: An Experiment that Changed the Course Allocation Mechanism at Wharton', NBER Working Paper No. 22448.

- Lee, R. S., and Shim, J. (2017), 'Will the Market Fix the Market? A Theory of Stock Market Competition and Innovation', Booth School of Business Working Paper.

- Cramton, P., and Shim, J. (2015), 'The High-frequency Trading Arms Race: Frequent Batch Auctions as a Market Design Response', Quarterly Journal of Economics, 130(4), 1547-621.

- Cachon, G. P., Kessler, J. B., and Othman, A. (2016), 'Course Match: A Large-scale Implementation of Approximate Competitive Equilibrium from Equal Incomes for Combinatorial Allocation', Operations Research, 65(2), 314-36.

- Che, Y.-K., Kojima, F., and Milgrom, P. (2013), 'Designing Random Allocation Mechanisms: Theory and Applications', American Economic Review, 103(2), 585-623.

Bulow, J., and Klemperer, P. (1996), 'Auctions Versus Negotiations', American Economic Review, 86(1), $180-94$

_ - (2009), 'Why Do Sellers (Usually) Prefer Auctions?', American Economic Review, 99(4), 1544-75. 
Calsamiglia, C., and Miralles, A. (2016), 'Catchment Areas and Access to Better Schools', CEMFI Working Paper.

Cantillon, E. (2017), 'Broadening the Market Design Approach to School Choice', Oxford Review of Economic Policy, 33(4), 613-34.

- Pesendorfer, M. (2006), 'Auctioning Bus Routes: The London Experience', in P. Cramton, Y. Shoham, and R. Steinberg (eds), Combinatorial Auctions, Cambridge, MA, MIT Press.

Cardinale, B. J., Duffy, J. E., Gonzalez, A., Hooper, D. U., Perrings, C., Venail, P., Narwani, A., Mace, G. M., Tilman, D., Wardle, D. A., Kinzig, A. P., Gretchen, C. D., Loreau, M., Grace, J. B., Larigauderie, A., Srivastava, D. S., and Naeem, S. (2012), 'Biodiversity Loss and its Impact on Humanity', Nature, 486(7401), 59-67.

Castillo, J. C., Knoepfle, D., and Weyl, E. G. (2017), 'Surge Pricing Solves the Wild Goose Chase', Stanford University Working Paper.

Che, Y.-K., Kim, J., and Kojima, F. (2015), 'Stable Matching in Large Economies', Columbia University Working Paper.

Chen, M. K., Chevalier, J. A., Rossi, P. E., and Oehlsen, E. (2017), 'The Value of Flexible Work: Evidence from Uber Drivers', NBER Working Paper No. 23296.

Chen, P., Egesdal, M., Pycia, M., and Yenmez, M. B. (2016), 'Manipulability of Stable Mechanisms', American Economic Journal: Microeconomics, 8(2), 202-14.

Chen, Y., and Takeuchi, K. (2010), 'Multi-object Auctions with Package Bidding: An Experimental Comparison of Vickrey and iBEA', Games and Economic Behavior, 68(2), 557-79.

Chernomaz, K., and Levin, D. (2012), 'Efficiency and Synergy in a Multi-unit Auction with and without Package Bidding: An Experimental Study', Games and Economic Behavior, 76(2), 611-35.

Chien, C. V. (2014), 'Startups and Patent Trolls', Stanford Technology Law Review, 17(Winter), 461-506.

Chu, C. (2009), 'Thirty Years Later: The Global Growth of ITQs and their Influence on Stock Status in Marine Fisheries', Fish and Fisheries, 10(2), 217-30.

Clements, M. (2018), The Walls of Nations, New York, Columbia University Press.

Coase, R. H. (1960), 'The Problem of Social Cost', Journal of Law and Economics, 3(October), 1-44.

Cohen, L., Gurun, U. G., and Kominers, S. D. (2015), 'Shielded Innovation', Harvard University Working Paper.

— _ - (2016), 'The Growing Problem of Patent Trolling', Science, 352(6285), 521-2.

_ _ _ (2017a), 'Empirical Evidence on the Behavior and Impact of Patent Trolls: A Survey', in D. D. Sokol (ed.), Patent Assertion Entities and Competition Policy, Cambridge, Cambridge University Press, 27-59.

_ _ _ (2017b), 'Patent Trolls: Evidence from Targeted Firms', NBER Working Paper No. 20322.

- Golden, J. M., Gurun, U. G., and Kominers, S. D. (forthcoming), "Troll” Check? A Proposal for Administrative Review of Patent Litigation', Boston University Law Review.

Cohen, P., Hahn, R., Hall, J. V., Levitt, S., and Metcalfe, R. (2016), 'Using Big Data to Estimate Consumer Surplus: The Case of Uber', NBER Working Paper No. 22627.

Coles, P., Cawley, J., Levine, P. B., Niederle, M., Roth, A. E., and Siegfried, J. J. (2010), 'The Job Market for New Economists: A Market Design Perspective', Journal of Economic Perspectives, 24(4), 187-206.

Cournot, A.-A. (1838), Recherches sur les Principes Mathématiques de la Théorie des Richesses, Chez L. Hachette.

Cramer, J., and Krueger, A. B. (2016), 'Disruptive Change in the Taxi Business: The Case of Uber', American Economic Review, 106(5), 177-82.

Cramton, P. (2017), 'Electricity Market Design', Oxford Review of Economic Policy, 33(4), 589-612.

- Ockenfels, A. (forthcoming), 'The German 4G Spectrum Auction: Design and Behavior, The Economic Journal, 128.

- Geddes, R. R., and Ockenfels, A. (2017), 'Markets in Road Use: Eliminating Congestion through Scheduling, Routing, and Real-time Road Pricing', University of Maryland Working Paper.

- Shoham, Y., and Steinberg, R. (eds) (2006), Combinatorial Auctions, Cambridge, MA, MIT Press.

- Kwerel, E., Rosston, G., and Skrzypacz, A. (2011), 'Using Spectrum Auctions To Enhance Competition In Wireless Services', Journal of Law and Economics, 54(S4), S167-88. 
Crawford, V. P. (2008), 'The Flexible-salary Match: A Proposal to Increase the Salary Flexibility of the National Resident Matching Program', Journal of Economic Behavior \& Organization, 66(2), $149-60$.

- (2016), 'Efficient Mechanisms for Level- $k$ Bilateral Trading', Oxford University Working Paper.

- Iriberri, N. (2007), 'Level- $k$ auctions: Can a Nonequilibrium Model of Strategic Thinking Explain the Winner's Curse and Overbidding in Private-value Auctions?', Econometrica, 75(6), 1721-70.

- Knoer, E. M. (1981), 'Job Matching with Heterogeneous Firms and Workers', Econometrica, 49(2), $437-50$

- Kugler, T., Neeman, Z., and Pauzner, A. (2009), 'Behaviourally Optimal Auction Design: Examples and Observations', Journal of the European Economic Association, 7(2-3), 377-87.

Day, R. W., and Cramton, P. (2012), 'Quadratic Core-selecting Payment Rules for Combinatorial Auctions', Operations Research, 60(3), 588-603.

- Milgrom, P. (2008), 'Core-selecting Package Auctions', International Journal of Game Theory, 36(3), 393-407.

Delacrétaz, D., Kominers, S. D., and Teytelboym, A. (2016), 'Refugee Resettlement', Oxford University Working Paper.

Dickerson, J. P., and Sandholm, T. (2014), 'Multi-organ Exchange: The Whole is Greater than the Sum of its Parts', in Proceedings of the Twenty-Eighth Conference on Artificial Intelligence, 1412-18.

Dimakopoulos, P. D., and Heller, C. (2015), 'Matching with Waiting Times: The German Entry-level Labour Market for Lawyers', Working Paper, Beiträge zur Jahrestagung des Vereins für Socialpolitik 2015: Ökonomische Entwicklung-Theorie und Politik, Session: Mechanism Design, No. B20-V1.

Dirzo, R., Young, H. S., Galetti, M., Ceballos, G., Isaac, N. J., and Collen, B. (2014), 'Defaunation in the Anthropocene', Science, 345(6195), 401-6.

Djankov, S., La Porta, R., Lopez-de Silanes, F., and Shleifer, A. (2003), 'Courts', Quarterly Journal of Economics, 118(2), 453-517.

Doğan, B. (2016), 'Responsive Affirmative Action in School Choice', Journal of Economic Theory, 165(September), 69-105.

Dubins, L. E., and Freedman, D. A. (1981), 'Machiavelli and the Gale-Shapley Algorithm', American Mathematical Monthly, 88(7), 485-94.

Duffie, D., Gârleanu, N., and Pedersen, L. H. (2005), 'Over-the-counter Markets', Econometrica, 73(6), $1815-47$.

Dur, U., Kominers, S. D., Pathak, P. A., and Sönmez, T. (forthcoming), 'The Demise of Walk Zones in Boston: Priorities vs. Precedence in School Choice', Journal of Political Economy.

Dwork, C. (2011), 'Differential Privacy', in H. C. A. van Tilborg and S. Jajodia (eds), Encyclopedia of Cryptography and Security, Springer, 338-40.

- Roth, A. (2014), 'The Algorithmic Foundations of Differential Privacy', Foundations and Trends in Theoretical Computer Science, 9(3-4) 211-407, Now Publishers.

Echenique, F., and Yenmez, M. B. (2015), 'How to Control Controlled School Choice', American Economic Review, 105(8), 2679-94.

Edelman, B. (2017), 'The Market Design and Policy of Online Review Platforms', Oxford Review of Economic Policy, 33(4), 635-49.

- Ostrovsky, M., and Schwarz, M. (2007), 'Internet Advertising and the Generalized Second-price Auction: Selling Billions of Dollars Worth of Keywords', American Economic Review, 97(1), 242-59.

Edgeworth, F. Y. (1881), Mathematical Psychics: An Essay on the Application of Mathematics to the Moral Sciences, Kegan Paul.

Ehlers, L., Hafalir, I. E., Yenmez, M. B., and Yildirim, M. A. (2014), 'School Choice with Controlled Choice Constraints: Hard Bounds versus Soft Bounds', Journal of Economic Theory, 153(September), $648-83$.

Einav, L., and Levin, J. (2014), 'Economics in the Age of Big Data', Science, 346(6210), 1243089.

Eisenmann, T. R., and Kominers, S. D. (2017), 'Making Markets', course notes.

- Parker, G., and Van Alstyne, M. W. (2006), 'Strategies for Two-sided Markets', Harvard Business Review, 84(10), 92-101. 
Ekins, P., Simon, S., Deutsch, L., Folke, C., and De Groot, R. (2003), 'A Framework for the Practical Application of the Concepts of Critical Natural Capital and Strong Sustainability', Ecological Economics, 44(2-3), 165-85.

Erdil, A., and Klemperer, P. (2010), 'A New Payment Rule for Core-selecting Package Auctions', Journal of the European Economic Association, 8(2-3), 537-47.

Ergin, H., Sönmez, T., and Ünver, M. U. (2014), 'Lung Exchange', Boston College Working Paper.

- — - (forthcoming), 'Dual-donor Organ Exchange', Econometrica.

Fama, E. F., Fisher, L., Jensen, M. C., and Roll, R. (1969), 'The Adjustment of Stock Prices to New Information', International Economic Review, 10(1), 1-21.

Feng, J., and Jaravel, X. (2015), 'Patent Trolls and the Patent Examination Process', Harvard University Working Paper.

Ferraro, P. J. (2008), 'Asymmetric Information and Contract Design for Payments for Environmental Services', Ecological Economics, 65(4), 810-21.

Fisman, R., and Sullivan, T. (2016), The Inner Lives of Markets: How People Shape Them-And They Shape Us, PublicAffairs.

Fleiner, T. (2003), 'A Fixed-point Approach to Stable Matchings and Some Applications', Mathematics of Operations Research, 28(1), 103-26.

- Jagadeesan, R., Jankó, Z., and Teytelboym, A. (2017), ‘Trading Networks with Frictions', Oxford University Working Paper.

Fradkin, A. (forthcoming), 'Digital Market Design and Inequality', in S. D. Kominers and A. Teytelboym (eds), Fair by Design: Economic Design Responses to Inequality, Oxford, Oxford University Press.

- Grewal, E., and Holtz, D. (2017), 'The Determinants of Online Review Informativeness: Evidence from Field Experiments on Airbnb', MIT Working Paper.

Friedman, M., and Schwartz, A. J. (1963), A Monetary History of the United States, Princeton, NJ, Princeton University Press.

Gale, D., and Shapley, L. S. (1962), 'College Admissions and the Stability of Marriage', American Mathematical Monthly, 69(1), 9-15.

Ghosh, A., and Roth, A. (2015), 'Selling Privacy at Auction', Games and Economic Behavior, 91(May), $334-46$.

- Ligett, K., Roth, A., and Schoenebeck, G. (2014), 'Buying Private Data without Verification', in Proceedings of the 15th ACM Conference on Economics and Computation, 931-48.

Glaeser, E. L., and Kominers, S. D. (forthcoming), 'Market Design in Developing-world Cities', in S. D. Kominers and A. Teytelboym (eds), Fair by Design: Economic Design Approaches to Inequality, Oxford, Oxford University Press.

_ _ Luca, M., and Naik, N. (forthcoming), 'Big Data and Big Cities: The Promises and Limitations of Improved Measures of Urban Life', Economic Inquiry.

Goeree, J. K., and Holt, C. A. (2010), 'Hierarchical Package Bidding: A Paper \& Pencil Combinatorial Auction', Games and Economic Behavior, 70(1), 146-69.

Goldfarb, A., and Tucker, C. E. (2011), 'Privacy Regulation and Online Advertising', Management Science, 57(1), 57-71.

Hafalir, I. E., Yenmez, M. B., and Yildirim, M. A. (2013), 'Effective Affirmative Action in School Choice', Theoretical Economics, 8(2), 325-63.

Hall, J. D. (2017), 'Pareto Improvements from Lexus Lanes: The Case for Pricing a Portion of the Lanes on Congested Highways', University of Toronto Working Paper.

Hall, J. V., and Krueger, A. B. (2016), 'An Analysis of the Labor Market for Uber's Driver-partners in the United States', NBER Working Paper No. 22843.

Hansen, M. C., Potapov, P. V., Moore, R., Hancher, M., Turubanova, S., Tyukavina, A., Thau, D., Stehman, S., Goetz, S., Loveland, T., Kommareddy, A., Egorov, A., Chini, L., Justice, C. O., and Townshend, J. R. G. (2013), 'High-resolution Global Maps of 21st-century Forest Cover Change', Science, 342(6160), 850-3.

Hassidim, A., Romm, A., and Shorrer, R. I. (2016), "'Strategic" Behavior in a Strategy-proof Environment', Harvard University Working Paper. 
Hassidim, A., Romm, A., and Shorrer, R. I. (2017a), 'Redesigning the Israeli Psychology Master's Match', American Economic Review, 107(5), 205-9.

- Marciano, D., Romm, A., and Shorrer, R. I. (2017b), 'The Mechanism Is Truthful, Why Aren't You?', American Economic Review, 107(5), 220-4.

Hatfield, J. W., and Kominers, S. D. (2012), 'Matching in Networks with Bilateral Contracts', American Economic Journal: Microeconomics, 4(1), 176-208.

— - (2015), 'Hidden Substitutes', Harvard University Working Paper.

- - (2017), 'Contract Design and Stability in Many-to-many Matching', Games and Economic Behavior, 101(January), 78-97.

- Milgrom, P. (2005), 'Matching with Contracts', American Economic Review, 95(4), 913-35.

- Kojima, F., and Narita, Y. (2016), 'Improving Schools through School Choice: A Market Design Approach', Journal of Economic Theory, 166(November), 186-211.

- Kominers, S. D., Nichifor, A., Ostrovsky, M., and Westkamp, A. (2013), 'Stability and Competitive Equilibrium in Trading Networks', Journal of Political Economy, 121(5), 966-1005.

Hayek, F. A. (1945), 'The Use of Knowledge in Society', American Economic Review, 35(4), 519-30.

Helm, D. (1990), The Economic Borders of the State, Oxford, Oxford University Press.

- Hepburn, C. (2012), 'The Economic Analysis of Biodiversity: An Assessment', Oxford Review of Economic Policy, 28(1), 1-21.

Helmers, C., Love, B., and McDonagh, L. (2013), 'Is There a Patent Troll Problem in the UK?', Fordham Intellectual Property, Media \& Entertainment Law Journal, 24(2), 509-53.

Hepburn, C., Pfeiffer, A., Pretis, F., and Teytelboym, A. (2017), 'Are We Running Out of Minerals?', Institute for New Economic Thinking Working Paper.

Hicks, J. R. (1939), 'The Foundations of Welfare Economics', The Economic Journal, 49(196), 696-712.

Hylland, A., and Zeckhauser, R. (1979), 'The Efficient Allocation of Individuals to Positions', Journal of Political Economy, 87(2), 293-314.

Iftekhar, M. S., Hailu, A., and Lindner, R. (2012), 'The Effect of Bidder Heterogeneity on Combinatorial Conservation Auction Designs', Environmental and Resource Economics, 53(1), 137.

Jagadeesan, R. (2017), 'Complementary Inputs and the Existence of Stable Outcomes in Large Trading Networks', Harvard University Working Paper.

Jayachandran, S., de Laat, J., Lambin, E. F., Stanton, C. Y., Audy, R., and Thomas, N. E. (2017), 'Cash for Carbon: A Randomized Trial of Payments for Ecosystem Services to Reduce Deforestation', Science, 357(6348), 267-73.

Jones, W., and Teytelboym, A. (forthcoming), 'The Local Refugee Match: Aligning Refugees' Preferences with the Capacities and Priorities of Localities', Journal of Refugee Studies.

Kagel, J. H., and Roth, A. E. (2000), 'The Dynamics of Reorganization in Matching Markets: A Laboratory Experiment Motivated by a Natural Experiment', Quarterly Journal of Economics, 115(1), 201-35.

- Lien, Y., and Milgrom, P. (2010), 'Ascending Prices and Package Bidding: A Theoretical and Experimental Analysis', American Economic Journal: Microeconomics, 2(3), 160-85.

_ _ _ (2014), 'Ascending Prices and Package Bidding: Further Experimental Analysis', Games and Economic Behavior, 85(1), 210-31.

Kamada, Y., and Kojima, F. (2012), 'Stability and Strategy-proofness for Matching with Constraints: A Problem in the Japanese Medical Match and its Solution', American Economic Review, 102(3), $366-70$.

- - (2015), 'Efficient Matching under Distributional Constraints: Theory and Applications', American Economic Review, 105(1), 67-99.

Kash, I. A., Friedman, E. J., and Halpern J. Y. (2012), 'Optimizing Scrip Systems: Crashes, Altruists, Hoarders, Sybils and Collusion', Distributed Computing, 25(5), 335-57.

_ _ (2015), 'An Equilibrium Analysis of Scrip Systems', ACM Transactions on Economics and Computation, 3(3), Article No. 13.

Kearns, M. (2017), 'Fair Algorithms for Machine Learning', in Proceedings of the 2017 ACM Conference on Economics and Computation, 1.

Kelso, Jr, A. S., and Crawford, V. P. (1982), 'Job Matching, Coalition Formation, And Gross Substitutes', Econometrica, 50(6), 1483-504. 
Kessler, J. B., and Roth, A. E. (2012), 'Organ Allocation Policy and the Decision to Donate', American Economic Review, 102(5), 2018-47.

— - (2014), 'Getting More Organs for Transplantation', American Economic Review, 104(5), 425-30.

Kesten, O. (2010), 'School Choice with Consent', Quarterly Journal of Economics, 125(3), 1297-348.

Keynes, J. M. (1936), The General Theory of Employment, Interest, and Money, Palgrave Macmillan.

Kiebzak, S., Rafert, G., and Tucker, C. E. (2016), 'The Effect of Patent Litigation and Patent Assertion Entities on Entrepreneurial Activity', Research Policy, 45(1), 218-31.

Kinzig, A. P., Perrings, C., Chapin, F. S., Polasky, S., Smith, V. K., Tilman, D., and Turner, B. (2011), 'Paying for Ecosystem Services_-Promise and Peril', Science, 334(6056), 603-4.

Klaus, B., and Klijn, F. (2005), 'Stable Matchings and Preferences of Couples', Journal of Economic Theory, 121(1), 75-106.

Klemperer, P. (2002), 'What Really Matters in Auction Design', Journal of Economic Perspectives, 16(1), 169-89.

- (2003), 'Why Every Economist Should Learn Some Auction Theory', in M. Dewatripont, L. Hansen, and S. Turnovsky (eds), Advances in Economics and Econometrics: Invited Lectures to 8th World Congress of the Econometric Society, Cambridge, Cambridge University Press.

- (2004), Auctions: Theory and Practice, Princeton, NJ, Princeton University Press.

- (2010), 'The Product-mix Auction: A New Auction Design for Differentiated Goods', Journal of the European Economic Association, 8(2-3), 526-36.

Kojima, F. (2012), 'School Choice: Impossibilities for Affirmative Action', Games and Economic Behavior, 75(2), 685-93.

- Pathak, P. A. (2009), 'Incentives and Stability in Large Two-sided Matching Markets', American Economic Review, 99(3), 608-27.

- Roth, A. E. (2013), 'Matching with Couples: Stability and Incentives in Large Markets', Quarterly Journal of Economics, 128(4), 1585-632.

Kominers, S. D., and Sönmez, T. (2016), 'Matching with Slot-specific Priorities: Theory', Theoretical Economics, 11(2), 683-710.

- Weyl, E. G. (2012), 'Holdout in the Assembly of Complements: A Problem for Market Design', American Economic Review, 102(3), 360-5.

Kőszegi, B. (2014), 'Behavioral Contract Theory', Journal of Economic Literature, 52(4), 1075-118.

Kyle, A. S., and Lee, J. (2017), 'Toward a Fully Continuous Exchange', Oxford Review of Economic Policy, 33(4), 650-75.

Leape, J. (2006), 'The London Congestion Charge', Journal of Economic Perspectives, 20(4), 157-76.

Levin, J., and Skrzypacz, A. (2016), 'Properties of the Combinatorial Clock Auction', American Economic Review, 106(9), 2528-51.

Lewis-Faupel, S., Neggers, Y., Olken, B. A., and Pande, R. (2016), 'Can Electronic Procurement Improve Infrastructure Provision? Evidence from Public Works in India and Indonesia', American Economic Journal: Economic Policy, 8(3), 258-83.

Leychkis, Y. (2007), 'Of Fire Ants and Claim Construction: An Empirical Study of the Meteoric Rise of the Eastern District of Texas as a Preeminent Forum for Patent Litigation', Yale Journal of Law \& Technology, 9(1), 193-232.

Leyton-Brown, K., Milgrom, P., and Segal, I. (2017), 'Economics and Computer Science of a Radio Spectrum Reallocation', Proceedings of the National Academy of Sciences, 114(28), 7202-9.

Li, S. (2017), 'Ethics and Market Design', Oxford Review of Economic Policy, 33(4), 705-20.

- (forthcoming), 'Obviously Strategy-proof Mechanisms', American Economic Review.

Liu, Q., and Pycia, M. (2016), 'Ordinal Efficiency, Fairness, and Incentives in Large Markets', Columbia University Working Paper.

Love, B. J. (2013), 'An Empirical Study of Patent Litigation Timing: Could a Patent Term Reduction Decimate Trolls without Harming Innovators?', University of Pennsylvania Law Review, 161(5), 1309-59.

- Helmers, C., Gaessler, F., and Ernicke, M. (2017), 'Patent Assertion Entities in Europe', in D. D. Sokol (ed.), Patent Assertion Entities and Competition Policy, Cambridge, Cambridge University Press, 104-29. 
Luca, M. (2016), 'Reviews, Reputation, and Revenue: The Case of Yelp.com', Harvard Business School Working Paper No. 12-016.

- (forthcoming), 'User-generated Content and Social Media', in S. Anderson, D. Strömberg, and J. Waldfogel (eds), Handbook of Media Economics, Elsevier.

McAfee, R. P., and McMillan, J. (1996), 'Analyzing the Airwaves Auction', Journal of Economic Perspectives, 10(1), 159-75.

- - Wilkie, S. (2010), 'The Greatest Auction in History', in J. J. Siegfried (ed.), Better Living Through Economics, Cambridge, MA, Harvard University Press, 168-84.

McKenzie, L. (1954), 'On Equilibrium in Graham's Model of World Trade and Other Competitive Systems', Econometrica, 22(2), 147-61.

Madhavan, A. (2000), 'Market Microstructure: A Survey', Journal of Financial Markets, 3(3), 205-58.

Mailath, G. J., and Postlewaite, A. (1990), 'Asymmetric Information Bargaining Problems with Many Agents', Review of Economic Studies, 57(3), 351-67.

Marszalec, D. (2016), 'Auctions for Complements: An Experimental Analysis', CIRJE Working Paper, Faculty of Economics, University of Tokyo.

- (forthcoming), 'Auctions for Quota: A Primer and Perspectives for the Future', Fisheries Research.

Melton, H. (2017), 'Market Mechanism Refinement on a Continuous Limit Order Book Venue: A Case Study', ACM SIGecom Exchanges, 16(1), 74-9.

Milgrom, P. (1989), 'Auctions and Bidding: A Primer', Journal of Economic Perspectives, 3(3), 3-22.

- (2000), 'Putting Auction Theory to Work: The Simultaneous Ascending Auction', Journal of Political Economy, 108(2), 245-72.

- (2004), Putting Auction Theory to Work, Cambridge, Cambridge University Press.

- (2007), 'Package Auctions and Exchanges', Econometrica, 75(4), 935-65.

- (2010), 'Simplified Mechanisms with an Application to Sponsored-search Auctions', Games and Economic Behavior, 70(1), 62-70.

- (2017), Discovering Prices: Auction Design in Markets with Complex Constraints, New York, Columbia University Press.

- Segal, I. (2017), 'Deferred-acceptance Auctions and Radio Spectrum Reallocation', Stanford University Working Paper.

- Tadelis, S. (2017), 'Artificial Intelligence and Market Design', Stanford University Working Paper.

Miller, A. R., and Tucker, C. E. (2011), 'Can Health Care Information Technology Save Babies?', Journal of Political Economy, 119(2), 289-324.

Miller, S. P. (2013), 'Where's the Innovation: An Analysis of the Quantity and Qualities of Anticipated and Obvious Patents', Virginia Journal of Law and Technology, 18(1), 1-58.

Mishra, D., and Parkes, D. C. (2007), 'Ascending Price Vickrey Auctions for General Valuations', Journal of Economic Theory, 132(1), 335-66.

Montgomery, W. D. (1972), 'Markets in Licenses and Efficient Pollution Control Programs', Journal of Economic Theory, 5(3), 395-418.

Moore, G. E. (1965), 'Cramming more Components onto Integrated Circuits', Electronics, 19 April, $114-17$.

Moraga, J. F.-H., and Rapoport, H. (2014), 'Tradable Immigration Quotas', Journal of Public Economics, 115(July), 94-108.

Morstyn, T., Teytelboym, A., and McCulloch, M. D. (2017), 'Bilateral Contract Networks for Peer-topeer Energy Trading,, Oxford University Working Paper.

Mullainathan, S., and Obermeyer, Z. (2017), 'Does Machine Learning Automate Moral Hazard and Error?', American Economic Review, 107(5), 476-80.

Muradian, R., Arsel, M., Pellegrini, L., Adaman, F., Aguilar, B., Agarwal, B., Corbera, E., Ezzine de Blas, D., Farley, J., Froger, G., et al. (2013), 'Payments for Ecosystem Services and the Fatal Attraction of Win-Win Solutions', Conservation Letters, 6(4), 274-9.

Myerson, R. B. (1981), 'Optimal Auction Design', Mathematics of Operations Research, 6(1), 58-73.

Naik, N., Kominers, S. D., Raskar, R., Glaeser, E. L., and Hidalgo, C. A. (2017), 'Computer Vision Uncovers Predictors of Physical Urban Change', Proceedings of the National Academy of Sciences, 114(29), 7571-6. 
Nemes, V., Plott, C. R., and Stoneham, G. (2008), 'Electronic BushBroker Exchange: Designing a Combinatorial Double Auction for Native Vegetation Offsets', University of Melbourne Working Paper.

Newman, N., Fréchette, A., and Leyton-Brown, K. (forthcoming), 'Deep Optimization for Spectrum Repacking', Communications of the ACM.

Niederle, M., and Roth, A. E. (2003), 'Unraveling Reduces Mobility in a Labor Market: Gastroenterology with and without a Centralized Match', Journal of Political Economy, 111(6), 1342-52.

_ _ (2005), 'The Gastroenterology Fellowship Market: Should There be a Match?', American Economic Review, 95(2), 372-5.

Nikzad, A., Akbarpour, M., Rees, M. A., and Roth, A. E. (2017), 'Financing Transplants' Costs of the Poor: A Dynamic Model of Global Kidney Exchange', Stanford University Working Paper.

Nozick, R. (1974), Anarchy, State, and Utopia, New York, Basic Books.

O'Hara, M. (1995), Market Microstructure Theory, Cambridge, MA, Blackwell.

Olivares, M., Weintraub, G. Y., Epstein, R., and Yung, D. (2012), 'Combinatorial Auctions for Procurement: An Empirical Study of the Chilean School Meals Auction', Management Science, 58(8), 1458-81.

Ostrovsky, M. (2008), 'Stability in Supply Chain Networks', American Economic Review, 98(3), 897-923.

Parkes, D. C., and Ungar, L. H. (2000), 'Iterative Combinatorial Auctions: Theory and Practice', in Proceedings of the Seventeenth National Conference on Artificial Intelligence, 74-81.

- Wellman, M. P. (2015), 'Economic Reasoning and Artificial Intelligence', Science, 349(6245), 267-72.

- Kalagnanam, J., and Eso, M. (2001), 'Achieving Budget-balance with Vickrey-based Payment Schemes in Exchanges', in Proceedings of the 17th International Joint Conference on Artificial Intelligence, 1161-8.

Pathak, P. A. (2011), 'The Mechanism Design Approach to Student Assignment', Annual Review of Economics, 3, 513-36.

Pentland, A. (2014), Social Physics: How Good Ideas Spread-The Lessons from a New Science, London, Penguin.

Prendergast, C. (2017), 'The Allocation of Food to Food Banks', Booth School of Business Working Paper.

Rassenti, S. J., Smith, V. L., and Bulfin, R. L. (1982), 'A Combinatorial Auction Mechanism for Airport Time Slot Allocation', Bell Journal of Economics, 13(2), 402-17.

Rawls, J. (1971), A Theory of Justice, Cambridge, MA, Harvard University Press, Belknap.

Rees, M. A., Dunn, T. B., Kuhr, C. S., Marsh, C. L., Rogers, J., Rees, S. E., Cicero, A., Reece, L. J., Roth, A. E., Ekwenna, O., Fumo, D. E., Krawiec, K. D., Kopke, J. E., Jain, S., Tan, M., and Paloyo, S. R. (2017), 'Kidney Exchange to Overcome Financial Barriers to Kidney Transplantation', American Journal of Transplantation, 17(3), 782-90.

- Kopke, J. E., Pelletier, R. P., Segev, D. L., Rutter, M. E., Fabrega, A. J., Rogers, J., Pankewycz, O. G., Hiller, J., Roth, A. E., Sandholm, T., Ünver, M. U., and Montgomery, R. A. (2009), 'A Nonsimultaneous, Extended, Altruistic-donor Chain', New England Journal of Medicine, 360(11), 1096-101.

Rees-Jones, A. (forthcoming), 'Suboptimal Behavior in Strategy-proof Mechanisms: Evidence from the Residency Match', Games and Economic Behavior.

Robertson, M., and Hayden, N. (2008), 'Evaluation of a Market in Wetland Credits: Entrepreneurial Wetland Banking in Chicago', Conservation Biology, 22(3), 636- 46.

Rochet, J.-C., and Tirole, J. (2003), 'Platform Competition in Two-sided Markets', Journal of the European Economic Association, 1(4), 990-1029.

_ _ (2006), 'Two-sided Markets: A Progress Report', RAND Journal of Economics, 37(3), 645-67.

Rosston, G. (2012), 'Incentive Auctions', Communications of the ACM, 55, 24-6.

Roth, A., and Schoenebeck, G. (2012), 'Conducting Truthful Surveys, Cheaply', in Proceedings of the 13th ACM Conference on Electronic Commerce, 826-43.

Roth, A. E. (1982), 'The Economics of Matching: Stability and Incentives', Mathematics of Operations Research, 7(4), 617-28. 
Roth, A. E. (1984), 'The Evolution of the Labor Market for Medical Interns and Residents: A Case Study in Game Theory', Journal of Political Economy, 92(6), 991-1016.

- (1990), 'New Physicians: A Natural Experiment in Market Organization', Science, 250(4987), $1524-8$

- (1991), 'A Natural Experiment in the Organization of Entry-level Labor Markets: Regional Markets for New Physicians and Surgeons in the United Kingdom', American Economic Review, 81(3), 415-40.

- (2002), 'The Economist as Engineer: Game Theory, Experimentation, and Computation as Tools for Design Economics', Econometrica, 70(4), 1341-78.

- (2008a), 'Deferred Acceptance Algorithms: History, Theory, Practice, and Open Questions', International Journal of Game Theory, 36(3), 537-69.

- (2008b), 'What Have We Learned from Market Design?', The Economic Journal, 118(527), 285-310.

- (2015), Who Gets What - and Why: The New Economics of Matchmaking and Market Design, Houghton Mifflin Harcourt.

- Peranson, E. (1999), 'The Redesign of the Matching Market for American Physicians: Some Engineering Aspects of Economic Design', American Economic Review, 89(4), 748-80.

- Sotomayor, M. (1990), Two-sided Matching: A Study in Game-theoretic Modeling and Analysis, vol. 18 of Econometric Society Monographs, Cambridge, Cambridge University Press.

- Xing, X. (1994), 'Jumping the Gun: Imperfections and Institutions Related to the Timing of Market Transactions', American Economic Review, 84(4), 992-1044.

- - (1997), 'Turnaround Time and Bottlenecks in Market Clearing: Decentralized Matching in the Market for Clinical Psychologists', Journal of Political Economy, 105(2), 284-329.

- Sönmez, T., and Ünver, M. U. (2004), 'Kidney Exchange', Quarterly Journal of Economics, 119(2), $457-88$.

- _ - (2005a), 'A Kidney Exchange Clearinghouse in New England', American Economic Review, 95(2), 376-80

_ - _ (2005b), 'Pairwise Kidney Exchange', Journal of Economic Theory, 125(2), 151-88.

_ _ - (2007), 'Efficient Kidney Exchange: Coincidence of Wants in Markets with Compatibilitybased Preferences', American Economic Review, 97(3), 828-51.

Roth, B. N. (forthcoming), 'Market Design Under Weak Institutions', in S. D. Kominers and A. Teytelboym (eds), Fair by Design: Economic Design Approaches to Inequality, Oxford, Oxford University Press.

- Shorrer, R. I. (2017), 'Making it Safe to Use Centralized Markets: $\varepsilon$-Dominant Individual Rationality and Applications to Market Design', MIT Working Paper.

Sandel, M. J. (2012), What Money Can't Buy: The Moral Limits of Markets, Macmillan.

Santos, G. (2005), 'Urban Congestion Charging: A Comparison between London and Singapore', Transport Reviews, 25(5), 511-34.

Scheffel, T., Pikovsky, A., Bichler, M., and Guler, K. (2011), 'An Experimental Comparison of Linear and Nonlinear Price Combinatorial Auctions', Information Systems Research, 22(2), 346-68.

Schmalensee, R., and Stavins, R. N. (2017), 'The Design of Environmental Markets: What Have We Learned from Experience with Cap and Trade?', Oxford Review of Economic Policy, 33(4), 572-88.

Schummer, J., and Abizada, A. (2017), 'Incentives in Landing Slot Problems', Journal of Economic Theory, 170, 29-55.

- Vohra, R. V. (2013), 'Assignment of Arrival Slots', American Economic Journal: Microeconomics, 5(2), 164-85.

Sen, A. (1985), Commodities and Capabilities, Oxford, Oxford University Press.

Sentance, A. (2003), 'Airport Slot Auctions: Desirable or Feasible?', Utilities Policy, 11(1), 53-7.

Sheffi, Y. (2004), 'Combinatorial Auctions in the Procurement of Transportation Services', Interfaces, $34(4), 245-52$.

Shortle, J., and Horan, R. D. (2013), 'Policy Instruments for Water Quality Protection', Annual Review of Resoure Economics, 5(1), 111-38.

Smith, A. (1759), The Theory of Moral Sentiments, printed for Andrew Millar, in the Strand, and Alexander Kincaid and J. Bell, in Edinburgh. 
Smith, A. (1778), An Inquiry Into the Nature and Causes of the Wealth of Nations, W. Strahan and T. Cadell, in the Strand.

Sönmez, T. (1997), 'Manipulation via Capacities in Two-sided Matching Markets', Journal of Economic Theory, 77(1), 197-204.

- (2013), 'Bidding for Army Career Specialties: Improving the ROTC Branching Mechanism', Journal of Political Economy, 121(1), 186-219.

- Switzer, T. B. (2013), 'Matching with (Branch-of-choice) Contracts at United States Military Academy', Econometrica, 81(2), 451-88.

- Ünver, M. U. (2010), 'Course Bidding at Business Schools', International Economic Review, 51(1), 99-123.

- - (2017), 'Market Design for Living-donor Organ Exchanges: An Economic Policy Perspective', Oxford Review of Economic Policy, 33(4), 676-704.

Stavins, R. N. (2011), 'The Problem of the Commons: Still Unsettled after 100 Years', American Economic Review, 101(1), 81-108.

Stoneham, G., Chaudhri, V., Ha, A., and Strappazzon, L. (2003), 'Auctions for Conservation Contracts: An Empirical Examination of Victoria's BushTender Trial', Australian Journal of Agricultural and Resource Economics, 47(4), 477-500.

Sunstein, C. R., and Thaler, R. H. (2003), 'Libertarian Paternalism is not an Oxymoron', University of Chicago Law Review, 70(4), 1159-202.

Sweeney, J., and Sweeney, R. J. (1977), 'Monetary Theory and the Great Capitol Hill Baby Sitting Co-op crisis: Comment', Journal of Money, Credit and Banking, 9(1), 86-9.

Tadelis, S. (2016), 'Reputation and Feedback Systems in Online Platform Markets', Annual Review of Economics, 8(October), 321-40.

Tisdell, J., and Iftekhar, M. S. (2013), 'Fisheries Quota Allocation: Laboratory Experiments on Simultaneous and Combinatorial Auctions', Marine Policy, 38(March), 228-34.

Tran, A. (2009), 'Can Procurement Auctions Reduce Corruption? Evidence from the Internal Records of a Bribe-paying Firm', Indiana University Working Paper.

Tucker, C. E. (2014), 'Patent Trolls and Technology Diffusion: The Case of Medical Imaging', MIT Working Paper.

United Nations High Commissioner for Refugees (2017), Global Trends, Report.

Varian, H. R. (2007), 'Position Auctions', International Journal of Industrial Organization, 25(6), $1163-78$.

Vickrey, W. S. (1961), 'Counterspeculation, Auctions and Competitive Sealed Tenders', Journal of Finance, 16(1), 8-37.

- (1969), 'Congestion Theory and Transport Investment', American Economic Review, 59(2), 251-60.

Westkamp, A. (2010), 'Market Structure and Matching with Contracts', Journal of Economic Theory, 145(5), 1724-38.

Weyl, E. G. (2010), 'A Price Theory of Multi-sided Platforms', American Economic Review, 100(4), $1642-72$.

Wilson, R. (1979), 'Auctions of Shares', Quarterly Journal of Economics, 93(4), 675-89.

Worm, B., Hilborn, R., Baum, J. K., Branch, T. A., Collie, J. S., Costello, C., Fogarty, M. J., Fulton, E. A., Hutchings, J. A., Jennings, S., et al. (2009), 'Rebuilding Global Fisheries', Science, 325(5940), 578-85.

Zervas, G., Proserpio, D., and Byers, J. W. (forthcoming), 'The Rise of the Sharing Economy: Estimating the Impact of Airbnb on the Hotel Industry', Journal of Marketing Research.

Zhu, H. (2011), 'Finding a Good Price in Opaque Over-the-counter Markets', Review of Financial Studies, 25(4), 1255-85. 